AperTO - Archivio Istituzionale Open Access dell'Università di Torino

\title{
IL-6, IL-17 and STAT3: a holy trinity in auto-immunity?
}

\section{This is the author's manuscript}

Original Citation:

Availability:

This version is available http://hdl.handle.net/2318/110715

since

Published version:

DOI: $10.2741 / 4054$

Terms of use:

Open Access

Anyone can freely access the full text of works made available as "Open Access". Works made available under a Creative Commons license can be used according to the terms and conditions of said license. Use of all other works requires consent of the right holder (author or publisher) if not exempted from copyright protection by the applicable law. 


\section{(2) \\ UNIVERSITÀ DEGLI STUDI DI TORINO}

This is an author version of the contribution published on:

Camporeale A, V. Poli

IL-6, IL-17 and STAT3: a holy trinity in auto-immunity?

FRONTIERS IN BIOSCIENCE (2012) 17

DOI: $10.2741 / 4054$

The definitive version is available at:

http://www.bioscience.org/2012/v17/af/4054/list.htm 


\title{
IL-6, IL-17 and STAT3: a holy trinity in auto-immunity?
}

\author{
Annalisa Camporeale ${ }^{1}$, Valeria Poli ${ }^{1}$ \\ ${ }^{I}$ Molecular Biotechnology Center, University of Turin, 10126 Turin, Italy
}

TABLE OF CONTENTS

1. Abstract

2. Introduction

2.1.IL-6 in the development of auto-immunity

2.1.1. IL-6 and Rheumatoid Arthritis

2.1.2.IL-6 and Multiple Sclerosis

2.1.3. IL-6 and Myocarditis

3. The discovery of Th17 cells shed light on the role of IL-6 in auto-immune diseases.

4. STAT3 enters the game

5. IL-6, IL-17 and STAT3: the holy trinity in auto-immunity?

6. The IL-6-IL-17-STAT3 loop in inflammation-driven tumourigenesis

7. Conclusions

8. Acknowledgments

9. References

\section{ABSTRACT}

Interleukin-6 (IL-6) is a pleiotropic cytokine involved in the regulation of the cross talk between haematopoietic/immune cells and stromal cells, including the onset and resolution of inflammation, responses to infection, tissue remodelling and cancer. It is produced, among others, by fibroblasts, endothelial cells, macrophages and lymphocytes. IL-6 can interact with both membrane-bound and soluble forms of its ligand-binding receptor, the IL-6Ralpha, triggering signalling via dimerization of gp130, the signalling subunit of the IL-6 receptor complex. This leads to the activation of the JAK/STAT pathway and mainly culminates in the activation of the STAT3 transcription factor. Both IL-6 and STAT3 have recently emerged as main regulators of the differentiation and function of Th17 cells, via a positive feedback loop enhancing expression and/or activation of IL-6 itself, IL-17 and STAT3. Dysregulated IL-6 production and signalling are associated with chronic inflammatory diseases, auto-immunity and cancer, and are the object of intense translational research as promising therapeutic targets.

\section{INTRODUCTION}

IL-6 was initially identified in the ' 80 s as a factor inducing the terminal maturation of B-lymphocytes into antibodyproducing plasma cells. It was then implicated in T lymphocytes survival and in stimulating proliferation and/or differentiation of various haematopoietic stem cell lineages (reviewed in (1)). Additionally, it was identified as an essential mediator of host responses to acute inflammation, including the acute phase response in the liver $(2,3)$. Most cell types, including T and Blymphocytes, phagocytic cells, fibroblasts, endothelial and epithelial cells, can produce IL-6 in response to a wide range of stimuli such as bacterial or viral infection, inflammation and inflammatory cytokines. Once produced, IL-6 participates in tissue defences and healing, regulating local influx and maturation of leukocytes and promoting tissue remodelling. IL-6 secretion is normally tightly controlled, and indeed its excessive and continuous production has been implicated in the pathogenesis of postmenopausal osteoporosis, auto-immune disorders, plasma-cell dyscrasias and many types of cancer (4).

IL-6 signalling (Figure 1) occurs through the assembly of a receptor complex composed of two subunits, the ligand binding IL-6Ralpha and the signal transducing gp130 (reviewed in (5)). Gp130 also acts as a signalling subunit for a family of cytokines structurally related to IL-6: Leukaemia Inhibitory Factor (LIF), Oncostatin M (OSM), Ciliary Neurotrophic Factor (CNTF), Interleukin-11 (IL-11), Interleukin-27 (IL-27), cardiotrophin-1, cardiotrophin-related cytokine (CLC), and neuropoietin (NPN) (reviewed in (6) and in (7)). In contrast with IL-6 and IL-11, which trigger the homodimerization of gp130, most of the other family members assemble a heterodimeric complex between gp130 and a second signalling molecule, the LIFRbeta, the OSMRbeta or the IL-27Ralpha (7). The common sharing of gp130 and the differential involvement of the LIFRbeta and OSMRbeta are likely explanations for the overlapping and diverging functions displayed by these cytokines. The IL-6Ralpha cytoplasmic domain is not required for signalling, and soluble IL-6Ralpha forms (sIL-6Ralpha) can act as agonists, conferring IL-6 responsiveness to cells that only harbour gp130 (reviewed in (8)), a phenomenon known as IL-6 trans-signalling. Circulating sIL-6Ralpha, generated by alternative splicing or, more frequently, by ADAM17-mediated shedding from the cell surface (9), is naturally present in body fluids of both humans and mice, and its production is specifically increased in a variety of pathological conditions such as infection, inflammation and tumour progression (10-16). Indeed, sIL-6R is abundantly produced in patients with chronic inflammatory disorders, where it contributes to disease progression. IL-6 trans-signalling plays an important role in controlling leukocyte infiltration at sites of acute and chronic inflammation/infection (12). Neutrophils, the first cells infiltrating 
inflamed areas, undergo caspase-dependent activation of the ADAM17 protease, which in turn promotes shedding and local release of the sIL-6R. In the presence of inflammation-driven IL-6 production, this allows IL-6 trans-signalling to act on stromal cells that lack the membrane-bound IL-6R, up-regulating the expression of adhesion molecules and chemokines such as ICAM-1, VCAM-1, CXCL1, CXCL5, CXCL6, CXCL8, CCL2 (17). These in turn promote recruitment of macrophages, involved in neutrophil clearance and antigen presentation, and lymphocytes (18). These events are essential for the resolution of the inflammatory reaction and for initiating acquired immunity. Accordingly, increased and prolonged neutrophil accumulation at sites of inflammation is observed in IL-6 deficient mice (19). The importance of maintaining IL-6 signaling/trans-signaling under tight regulation is highlighted by the observation that under inflammatory conditions also gp130 can be produced in a soluble form that acts as a specific antagonist of IL-6 trans-signalling (20).

The interaction of IL- 6 with its receptor complex triggers the activation of associated JAK kinases, leading to the phosphorylation of five tyrosine residues on the cytoplasmic portion of gp130 (21). The phosphotyrosine residues in turn allow recruitment and activation of members of the Signal Transducer and Activator of Transcription family of transcription factors on one hand, and on the other hand of the SHP2 adaptor, leading to the activation of the Ras-MAP kinase pathway that mainly culminates in the induction of members of the C/EBP family of transcription factors (22). Finally, SOCS3, a STAT3 immediate early target gene, is recruited to the same phosphotyrosine residue as SHP2, mediating a negative feedback via inactivation of JAKs (23). STAT factors mediate the signalling downstream of cytokine and growth factor receptors. They become activated by JAK-mediated tyrosine-phosphorylation, upon which they form anti-parallel dimers that concentrate into the nucleus regulating the expression of target genes (24). All members of the IL-6 cytokine family were shown to be able to activate STAT3 and, to a lesser extent, STAT1.

STAT3 is recognized as the main mediator of IL-6 functions. Its activation occurs not only downstream of all members of the IL- 6 family of cytokines, but also of a great number of other cytokines, growth factors and oncogenes including leptin, IL12, Interferons, IL-10, G-CSF and Src (25). STAT3 itself is considered an oncogene, since it is constitutively tyrosinephosphorylated in a high percentage of tumours and tumour-derived cell lines of both liquid and solid origin, where its inhibition often triggers growth arrest and/or cell death (26-29).

STAT3 was initially identified as Acute Phase Response Factor (APRF), a DNA-binding activity appearing in IL-6treated hepatocytes and interacting with an Acute Phase Response Element (APRE) on the promoter of several IL-6-responsive genes (30). Molecular cloning identified then STAT3/APRF as the EGF-dependent factor binding to a sis-inducible element on the c-fos promoter (31-33). STAT3 can form both homo- and hetero-dimers with STAT1 and binds to sequences very similar to the GAS sites, the typical STAT1 recognition elements (34).

Both in vitro and in vivo studies have shown that one of the peculiar characteristics of STAT3 is its capacity to activate different sets of genes in different cell types. This is probably achieved through specific interactions with distinct transcription factors/co-factors in different cell and promoter contexts (e.g. AP1, NF-kB, CBP/p300, NCoA-1/SRC-1, NCoR2, PCAF, GCN5, mSin3, HDACs) (35-39). In addition, STAT3 exists in two alternatively spliced forms, the full length STAT3alpha and the truncated STAT3beta, which lacks the carboxy-terminal activation domain and was initially considered as a dominant negative form $(40,41)$, but was recently shown to exert both negative and positive effects on transcription (42). The final outcome of STAT3 activation in a specific cellular compartment will thus likely depend on the physiological/pathological context, which in turn will determine a specific cytokine/growth factor milieu and therefore coordinated activation of different factors including STAT3 (alpha and/or beta).

In this review, we summarize the current knowledge about the role of IL-6 in several auto-immune diseases, and correlate it to a pathogenetic mechanism involving the transcription factor STAT3 and the action of T helper 17 cells. The relevance of this IL-6-IL-17-STAT3 loop is then examined in inflammation-related tumourigenesis, where the IL-6/STAT3 axis is already known to play a crucial role.

\subsection{IL-6 in the development of auto-immunity}

Failure of the immunological safeguard mechanisms leading to discriminate self from non-self results in auto-immune diseases, which can affect many organs and tissues including thyroid, pancreas, adrenal glands, red blood cells and connective tissues (skin, muscle and joints). Auto-immune diseases can be either organ-specific, such as the pancreas in insulin-dependent diabetes, the thyroid in Hashimoto's thyroiditis and Graves' disease and the heart in myocarditis, or non-organ-specific, such as rheumatoid arthritis, multiple sclerosis, lupus erythematosus and myasthenia gravis (43). Auto-immune diseases can have many different causes and the exact aetiology of acquired auto-immunity is still not clear. A leading hypothesis to explain the onset of several different auto-immune diseases is that the immune response mounted against infectious agents can lead to break the tolerance versus self-antigens sharing common antigenic features (44). Auto-immune reactions share several common features like development of auto-antibodies, $\mathrm{T}$ cell proliferation and activation, tissue damage and increased production of proinflammatory cytokines like TNFalpha, IL-1, IL-2, IL-17, IL-6 and IFNgamma (45-48). There are abundant clinical data suggesting that IL-6 plays critical roles in the pathogenesis of auto-immune diseases, which have been dissected through the analysis of several animal models. 


\subsubsection{IL-6 and rheumatoid arthritis}

Rheumatoid arthritis (RA) is a common human auto-immune disease that affects joints and occasionally other tissues (reviewed in (49)). It is characterized by chronic inflammation of the synovial joints, excess synovial fluid production and development of a synovial pannus. The pannus is a membrane of granulation tissue covering the normal surface of the articular cartilages, which leads to destruction of the articular cartilage and bone erosion (50). Activation of immune cells is observed, as well as high local production of pro-inflammatory cytokines such as TNFalpha, IL-1 and IL-6, which are thought to play a central pathogenic role $(51,52)$. Both serum and synovial fluids of patients with active RA or juvenile rheumatoid arthritis display very high levels of IL-6 $(53,54)$, believed to act both locally and systemically $(52,55)$. Moreover, also synovial sIL-6R levels increase with disease progression (56). In addition to stimulating B and T cell functions, in conjunction with sIL-6R $\alpha$ IL-6 can activate the production of a subset of chemokines and adhesion molecules by endothelial cells (19), which lack membrane-bound IL-6R, and induce osteoclasts formation and activation $(56,57)$. Several studies have suggested that synovial fibroblasts (SFs) may have a critical pathogenic role via the production of proinflammatory cytokines and of proteases, such as matrix metalloproteinases, responsible for tissue destruction (58). Data on the role of IL-6 in SFs are contrasting. SFs are devoid of IL-6R and soluble IL-6R must therefore be present in order to elicit an IL-6 response (59). Mihara et al. reported IL-6 trans-mediated-mediated stimulation of SF proliferation (60). In contrast, Nishimoto and co-authors reported that IL-6 plus sIL-6Ralpha inhibits TNFalpha-induced SF proliferation. Since TNFalpha induces IL-6 production, IL-6 would in this case be part of a negative feedback loop (61). Although the exact IL-6-mediated pathogenic mechanism in RA is still incompletely understood, remarkably a humanized antiIL-6R monoclonal antibody (62) has been recently approved for the treatment of moderate to severe RA in adult patients not responding to previous therapy with one or more disease-modifying anti-rheumatic drug(s) (63).

Several models of arthritis have been established in the mouse and rat. The one that perhaps resembles RA more closely is collagen-induced arthritis (CIA), which elicits an auto-immune response against cartilage components (64). CIA is induced by immunization with autologous or heterologous type II collagen in susceptible DBA/ $1 \mathrm{~J}$ mice, leading to break tolerance against murine collagen thus initiating the disease. CIA resembles RA in a number of features including chronic proliferative synovitis with infiltration of polymorphonuclear and mononuclear cells, pannus formation, cartilage degradation, bone erosion and fibrosis. Antigen induced arthritis (AIA) (65) is a mono-articular chronic form of immunological arthritis triggered by intra-articular injection of methylated bovine serum albumin (mBSA) in susceptible strains of mice (C57BL/6 and BALB/c) previously sensitized by immunization with the same antigen. Also AIA reproduces many features of RA such as synovial lining hyperplasia, proliferation of sublining cells, infiltration of inflammatory cells, revascularization, pannus formation and articular cartilage destruction. Both CIA and AIA are considered T-cell dependent arthritides. Finally, zymosan-induced arthritis (ZIA) (66) is a purely inflammatory model of proliferative arthritis, triggered by direct injection of the inflammatory compound zymosan A into the knee joint cavity and not dependent on the adaptive immune response. Indeed, zymosan A, which is a ligand for toll-like receptor 2 as well as an activator of the alternative complement pathway, triggers local activation of the innate immune system causing inflammation in the injected joint.

Making use of IL-6 deficient mice several groups have demonstrated a pathogenic role of IL-6 in experimentally induced auto-immune arthritis. IL-6 deficiency results in partial to complete resistance to CIA, as judged by tissue damage, with reduction of both humoral and cellular responses to type II collagen and a shift toward a Th2-type immune response (67, 68). Comparable results have been obtained in AIA, where lack of IL-6 resulted in strongly reduced disease incidence and score and in protection from cartilage destruction and osteoclasts activation $(69,70)$, correlating with lower auto-antibody titers and reduced specific proliferative T cell responses. There are indications that both systemic and local IL- 6 production are involved in disease pathogenesis. Indeed, recombinant IL-6 injected either sub-cutaneously or locally in the knee joint could completely or partially restore sensitivity to AIA (70). Moreover, IL-6 production by bone marrow-derived haematopoietic cells must play an important role, since bone marrow transfer from a sensitised donor can transfer AIA to wild type mice depleted from B and T cells only if derived from an IL-6-sufficient mouse (71). In the ZIA model, the absence of IL-6 results in acute inflammation (characterized by neutrophil influx) and increased cartilage destruction. However, wild type mice develop more severe joint inflammation, with enhanced infiltration of monocytes and osteophyte formation during the chronic phase (72-74), suggesting a major role for IL-6 in the transition from the acute to the chronic phase in ZIA (reviewed in (75)). Local IL-6 production may act via IL-6 trans-signalling, since its specific blockade via sgp130 alleviates disease symptoms, while intra-articular administration of hyper IL-6, a recombinant protein generated by the fusion between IL- 6 and sIL-6Ralpha, can restore arthritis in IL- $6^{-/ 2}$ mice (13).

In conclusion, there is a general agreement that IL-6 plays a pathogenic role in all three models of arthritis examined, with particularly clear-cut results obtained in the two models of immunological arthritides that more closely resemble RA. Although the exact mechanism through which IL-6 exerts its pathogenic role is still not completely elucidated, it is likely to occur at multiple levels including i) promotion and maintenance of the chronic inflammatory response both systemically and locally, which in turn contributes to stimulating and amplifying T-cell dependent B cell responses to arthritogenic antigens; ii) induction of osteoclastogenesis and osteoclasts activity and iii) enhancing the production of molecules contributing to tissue destruction such as prostaglandins and nitric oxide by monocytes and synovial fibroblasts. On the other hand, TNFalpha and ILlbeta are both amply recognised as important players in the pathogenesis of RA and of other forms of arthritis, and both are potent inducers of IL-6 synthesis. It is thus not surprising that IL-6 may mediate at least some of their arthritogenic effects. Interestingly, the inflammatory polyarthritis caused by expression of an abnormally stable form of human TNFalpha in transgenic 
mice develops normally in IL- $6^{-/ 2}$ mice (67), suggesting that the need for IL-6 can be bypassed when the production of key inflammatory cytokines is outwith physiological means of control.

\subsubsection{IL-6 and multiple sclerosis}

Multiple sclerosis (MS) is an inflammatory disease of the central nervous system characterized by inflammation, demyelination and axon degeneration and leading to muscle weakness and ataxia. Its aetiology remains unknown and disease processes are still poorly understood. The observation that immunosuppressive treatment with cyclophosphamide (76), cladribine (77) or mitoxantrone (78) can limit disease activity suggested that MS is an immunologically mediated disease.

Several studies identify IL-6 as an important player in the onset and exacerbation of MS, since its levels are increased in the serum and cerebrospinal fluid of MS patients (79-81), in MS lesions $(82,83)$ and in mononuclear cells from cerebrospinal fluid and blood of MS patients (84). Auto-immune reactivity against minor components of myelin are thought to play an important role in the pathogenesis of multiple sclerosis. In particular, MS patients exhibit a predominant $\mathrm{T}$ cell response to myelin oligodendrocyte glycoprotein (MOG), which is rarely observed in the serum of healthy controls $(85,86)$.

Synthetic MOG peptides (pMOG) or myelin basic protein (MBP) are encephalitogenic in $\mathrm{H}-2^{\mathrm{b}}$ strains of mice such as C57BL/6 and 129, where they can induce experimental auto-immune encephalomyelitis (EAE), the best experimental model of MS so far. EAE is characterized by an ascending paralysis correlating with inflammation and tissue damage (87). Pathological features of EAE are perivascular inflammatory infiltrates of lymphocytes, macrophages and microglia in the brain and spinal cord, correlating with areas of demyelination. Affected animals show high levels of IL-6 in the central nervous system, high autoantibody levels against myosin and tissue infiltration of myelin-specific Th1 cells.

Remarkably, IL-6-deficient mice were completely resistant to EAE, showing neither clinical symptoms nor inflammatory infiltrate in the brain and spinal cord (88-92). A shift toward a Th2-type anti-inflammatory response was observed, with production of IL-10 and IL-4 (89-92). Lack of inflammatory infiltrate correlated with decreased VCAM-1 and ICAM-1 expression by endothelial cells in the central nervous system. IL-6-dependent up-regulation of these adhesion molecules is thought to cause breakdown of the blood brain barrier and T cell entry $(89,91,93)$.

Although serum titers of anti-MOG auto-antibodies were decreased in the IL- $6^{-/-}$mice, this could not per se warrant protection as B-lymphocytes are not required for EAE pathogenesis (89). Accordingly, the partial rescue of disease development observed upon injection of recombinant IL-6 did not correlate with increased antibody production (88). T cell priming, impaired in pure C57BL/6 IL-6 deficient mice, was in contrast normal in the (C57BL/6x129) F1 genetic background even though these were still protected from disease development $(88,90,92)$. Protection cannot therefore be ascribed to impaired T cell reactivity either. Accordingly, T cell lines exhibiting high proliferative responses to MOG could be derived from both mutant and wild type mice (88). Interestingly, IL- $6^{-/-} \mathrm{T}$ lymphocytes were unable to confer EAE to an IL- $6^{+/+}$recipient (88), while IL- ${ }^{+/+} \mathrm{T}$ cells could successfully transfer EAE, but to a wild type recipient mouse only, suggesting that the pathogenic role of IL-6 in EAE rests on both T cell-dependent and independent functions. Accordingly, transgenic mice producing IL-6 specifically in the cerebellum show EAE development in this region rather than in the spinal cord, suggesting that localized secretion of IL-6 is enough to redirect the disease (94). Which other players are involved in addition to T cells? IL-6 appears to be important to establish the local perivascular inflammatory process characteristic of the disease, as already suggested by the failure of IL- $6^{+/+} \mathrm{T}$ cells to elicit inflammation when transferred into IL- $6^{-1-}$ recipients (88). Moreover, disease in the IL- $6^{-/-}$mice can be partially rescued by injection with IL-8, a chemo-attractant whose secretion by endothelial cells is induced by IL-6 in combination with sIL-6R (88). Finally, injection of superantigen (staphylococcal enterotoxin B) increased VCAM-1 expression in brain endothelium and partially reversed resistance of IL- $6^{-/-}$mice to EAE (95). In conclusion, IL-6 plays a fundamental role in the pathogenesis of autoimmune encephalomyelitis, both by stimulating an encephalitogenic $\mathrm{T}$ cell response and by establishing the local inflammatory response via the induction of chemokines and the activation of the endothelium, possibly also increasing the permeability of the blood-brain barrier (96). These observations highlight the relevance of feedback interactions between stromal cells and $\mathrm{T}$ cells in the development of MS and likely other auto-immune diseases, and suggest that IL-6 production by both compartments plays a crucial role in this cross-talk.

\subsubsection{IL-6 and myocarditis}

Acute myocarditis can initiate a chronic immune-mediated inflammation of the heart, possibly leading to dilated cardiomyopathy (DCM) with chronic heart failure. In many developing countries, myocarditis remains a significant cause of morbidity and mortality in the young adult. The main recognized cause is a viral infection of the heart, particularly with strains of the coxsackievirus. Possible mechanisms include direct viral destruction of cardiac myocytes, which can lead to T-cell-mediated auto-immune injury, and viral-mediated endothelial injury that triggers an inflammatory response leading to tissue damage including necrosis. Bacterial pathogens, hypersensitivity reactions, cancer or pre-existing systemic diseases such as the ChurgStrauss syndrome, are also implicated as co-factors (97-99). Elevated levels of Fas and Fas ligand as well as elevated IL-10 serum levels are predictors of poor prognosis in patients with fulminant myocarditis $(100,101)$.

Experimental auto-immune myocarditis (EAM) is an auto-immune disorder that resembles $\mathrm{CD}^{+}{ }^{+}$-mediated human heart inflammation. It can be induced in susceptible mice (BALB/c, CBA/J and A/J) by infection with coxsackievirus B3 (CVB3) 
(102) or by immunization with cardiac myosin or derived peptides (103). Cytokines like TNFalpha (104), IL-4 (105) and IL-12 $(106,107)$ are essential for the development of the disease, whereas IFNgamma is protective (108). Several studies have demonstrated that also IL-6 plays an important role in EAM. Indeed, IL-6 deficient mice developed a milder disease, with low prevalence and reduced severity (109). Decreased VCAM-1 and ICAM-1 expression on endothelial cells and lower levels of complement $\mathrm{C} 3$ and TNFalpha are responsible for the less efficient recruitment of auto-reactive $\mathrm{T}$ cells to the heart of IL-6deficient mice. Of note, the proliferation of IL-6-deficient auto-reactive $\mathrm{CD}^{+} \mathrm{T}$ cells is impaired. Similar to what observed also in RA and MS models, specific auto-antibody levels are lower in the IL- $6^{-/-}$mice as compared to wild type mice, but this is not responsible for the altered course of myocarditis.

The pathogenic role of IL-6 in auto-immunity is probably not limited to the above described pathologies, as abundant IL-6 production and beneficial effects of IL-6 neutralization have been observed in other auto-immune diseases such as uveitis or systemic lupus erythematosus (62).

\section{THE DISCOVERY OF TH17 CELLS SHED LIGHT ON THE ROLE OF IL-6 IN AUTO-IMMUNE DISEASES}

The above reported findings all point towards an important role of IL- 6 in mediating CD4 ${ }^{+} \mathrm{T}$ cell responses and chronic local and systemic inflammation, leading to the development of auto-immunity. This was to a certain extent puzzling, since until a few years ago inflammation and auto-immune diseases were thought to be caused by the activation of CD4 ${ }^{+} \mathrm{T}$ helper 1 (Th1) cells, not functionally linked to IL-6 production.

Th1/Th2 cell polarization is a central paradigm in T-cell mediated immunity. These cells differentiate from naive populations of $\mathrm{CD}^{+}$lymphocytes exposed to specific stimuli and cytokine milieu, and in turn are characterized by distinct repertoires of cytokine production (reviewed in (110)). Th2 responses, characterized by IL-4, IL-5, IL-9 and IL-13 secretion, are classically linked to antibody-mediated responses and allergy, whereas Th1 cells, characterized by secretion of IFNgamma, IL-2 and TNFalpha, were generally associated with T cell-mediated responses to intracellular pathogens and auto-immune diseases. The finding that mice lacking IFNgamma, the main Th1-driving cytokine, still developed inflammatory and auto-immune diseases $(106,107,111-115)$, suggested however the involvement of other players. Additionally, IL-12Rb2 $2^{-/-}$and IL-12p35 $5^{-/-}$ mice (116-118), which lack critical components of the Th1-IFNgamma pathway, were highly susceptible to inflammatory autoimmune diseases. These findings questioned the role of Th1 $\mathrm{CD}^{+} \mathrm{T}$ cells in auto-immune pathogenesis and set the stage for the search of other players. A novel effector lineage of T helper cells, the so-called Th17 cells, characterized by the production of IL17 and involved both in providing defence against extracellular bacteria and in mediating inflammation, was indeed recently identified $(119,120)$. IL-17 belongs to the small IL-17A-F family of cytokines, which is generally thought to enhance inflammation by stimulating the recruitment of other immune cells to peripheral tissues (121-123). Recent studies report that excessive IL-17 production exerts harmful effects in auto-immune and chronic inflammatory disorders in both the human and the mouse, because of its ability to trigger tissue damage. The important role of Th17 cells in human immune-mediated/inflammatory diseases has been suggested by the isolation of IL-17-producing cells in patients with contact dermatitis $(124,125)$ and in both brain lesions and mononuclear cells isolated from blood and cerebrospinal fluids of multiple sclerosis patients (126-128). Moreover, IL-17 is detectable in the synovial fluid from rheumatoid arthritis patients and can enhance osteoclastogenesis by inducing the receptor activator of NF-kB ligand (RANKL) on mesenchymal cells (129). Consistently, IL-17 plays a critical role in a model of bone loss induced by local inflammation, suggesting that Th17 cells may play a role in the destruction phase of auto-immune arthritis (130).

IL-17 critical role in auto-immune conditions has been extensively demonstrated also in mouse models. IL-17A gene inactivation suppressed the development of EAE, CIA and the arthritic disorders that develop in IL-1 Ra ${ }^{-/ /}$mice $(116,131-133)$. Mice deficient for RORgammat, a transcription factor required for IL-17 differentiation, show attenuated EAE (134). In addition, IL-17-producing cells are critical for EAM pathogenesis, and its depletion reduces disease severity $(135,136)$. IL-17 is also increased in lymphocytes derived from mice with EAE (137) and its neutralization during the elicitation phase suppresses disease development (138). The demonstration that adoptive transfer of specific Th17, but not Th1, cells induces EAE (138) has unambiguously established a pathogenic role for these cells. SKG mice, which carry a homozygous G-to-T substitution in the ZAP-70 gene and spontaneously develop an auto-immune arthritis-like disease when housed under non specific pathogen free conditions, show massive infiltration of IL-17 secreting cells in the joints and high local expression of IL-17 mRNA (113, 114). Accordingly, the transfer of $\mathrm{CD}^{+} / \mathrm{IL}-17^{-/-}$cells from SKG mice into Rag2 ${ }^{-/}$mice fails to induce arthritis, confirming the essential role of IL-17-producing Th17 cells in this model (114).

The link between the well documented pathogenic role of IL- 6 and that of IL-17/Th17 cells in auto-immunity was provided by the exciting finding that the differentiation of Th17 cells from naïve T cells, occurring in the periphery, requires the action of IL-6 combined, at least in mice, with transforming growth factor beta (TGFbeta) $(114,139)$. Moreover, in vivo Th17 differentiation in experimental auto-immune uveoretinitis (EAU) is impaired in the absence of IL-6, leading to disease protection (140). Interestingly, in vitro stimulation of naive $\mathrm{CD}^{+} \mathrm{T}$ lymphocytes with TGFbeta alone triggers the generation of regulatory $\mathrm{T}$ lymphocytes (Treg), another $\mathrm{CD}^{+}{ }^{+} \mathrm{T}$ cell subset with the ability to suppress immune responses against self- and non selfantigens and involved in the process of auto-immunity, transplant rejection, infectious diseases and cancer. Moreover, IL-6 transsignalling can block Treg development through up-regulation of SMAD7, which inhibits TGFbeta signalling thus decreasing 
tolerance and perpetuating chronic inflammatory diseases (141). It is indeed postulated that the Treg and Th17 lineages are somewhat related, with their specific differentiation being mutually exclusive $(142,143)$. However, the functional segregation of the different types of $\mathrm{CD}^{+}$Th lymphocytes is likely not as rigid as initially thought. For example, McGeachy and colleagues have demonstrated that activated Th17 cells continuously stimulated with TGFbeta and IL-6 can down-regulate the expression of genes encoding for several pro-inflammatory chemokines and initiate the production of IL-10 (144), thus switching to an antiinflammatory function. This may represent a negative feedback mechanism contributing to control Th17 pro-inflammatory responses. Until recently, human Th17 cells were considered different from their murine counterparts, since they express also Th1-related proteins such as IL-12R beta2 and T-bet, they produce both IL-17A and IFNgamma and, upon IL-12 stimulation, and they are able to shift to a Th1 phenotype (145). Moreover, in addition to IL-6 they require IL-1beta and IL-23 but not TGFbeta for their in vitro differentiation. However, also murine Th17 cells have been recently shown to be able to convert into Th1-like lymphocytes (146-148), and to rapidly switch to IFNgamma production in EAE (149) and in a model of type I insulin-dependent diabetes mellitus (150). Thus, the main difference between the murine and human system appears to be the requirement for TGFbeta (151).

Other pro-inflammatory cytokines have the ability to enhance Th17 responses, at least in vivo. For example IL-1beta $\square$ which is abundantly present in MS lesions (152), plays a central role upstream of IL-17 in promoting EAE since IL-1 $\mathrm{R}^{-/ /}$mice are resistant to the disease due to a specific defect in the Th17 response (153). IL-23, produced by activated antigen presenting cells, appears to play a prominent role in sustaining Th17 responses and chronic lesions, since IL-23-deficient mice contain very few Th17 cells and are protected from auto-immune diseases such as EAE and CIA $(136,138,154,155)$. In addition, IL-17 was shown to promote EAM in an IL-23-dependent way (136). Indeed, neutralization of either IL-17 or IL-23 ameliorates heart disease even if priming and proliferation of myosin-specific Th1 CD4 $4^{+}$cells are not affected. IL-22 is also abundantly released by Th17 cells in response to IL-23, supporting the idea that IL-23 can modulate Th17 cells effector functions (156). A crucial role for IL-22 has been shown in innate skin immunity, where it appears to directly increase the innate response against pathogens in keratinocytes (157). Both IL-17 and IL-22 were suggested to also induce endothelial cells of the blood-brain barrier to secrete cytokines and chemokines such as MCP-1, IL-6 and CXCL8. These in turn favour disruption of the tight-junctions and increased vessels permeabilization, thus promoting transmigration of $\mathrm{CD}^{+} \mathrm{T}$ lymphocytes (126). IL-21 was shown to drive Th17 differentiation in vitro $(158,159)$, but its activity is not critical in vivo since IL-2 $1^{-/ 2}$ and IL-2 $1 \mathrm{R}^{-/ 2}$ mice develop severe EAE and EAM, sustained by IL-6 $(159,160)$. Recently, GM-CSF was also proposed to play a critical role in the development and survival of Th17 cells, since it can stimulate dendritic cells to produce IL-6 and IL-23 (161).

Psoriasis is another chronic inflammatory disease where IL-6, together with T-cell mediated immune responses, is known to play a critical role (162-166). Recently, psoriasis patients were shown to display preponderance of the IL-23/Th17 axis $(167,168)$, abnormal Th1 responses with elevated IFNgamma and TNFalpha levels (169), and defective activity of Tregs (168, 170). It was shown that overproduction of IL-6 by endothelial cells and antigen-presenting cells in the lesions lead to reduced Treg activity and subsequent hyper activation and proliferation of infiltrating $\mathrm{T}$ lymphocytes, contributing to $\mathrm{CD}^{+} \mathrm{T}$ cells chronic expansion and driving Th17 differentiation (168). Indeed, Th17 cells have been recently observed in cell suspensions from psoriatic skin (171), and IL-17 neutralization arrests disease progression (170).

These observations collectively support a generalized pathogenic mechanism leading to chronic inflammation and, under certain circumstances, to auto-immunity, based on a positive circular feedback loop where continuous local and systemic production of IL- 6 sustains and is in turn sustained by local differentiation and concentration of Th17 cells. An important role is played in this context by IL-6 trans-signalling. Indeed, both IL-6 trans-signalling blockade and IL-6 deficiency are associated with reduced infiltration and increased apoptosis of $\mathrm{T}$ lymphocytes in several models of chronic inflammation $(11,172-175)$. For example, IL-6 deficiency leads to impaired peritoneal infiltration of IFNgamma- and IL-17-secreting cells and down-regulation of IL-6R expression (175). IL-6 trans-signalling may directly affect T cell activation, trafficking and apoptosis $(11,14,15,172)$, activities already associated with IL-6 itself (176-178). Interestingly, IL-6R expression is restricted to naïve and central memory, not effector, $\mathrm{T}$ cell subsets both in human and in the mouse $(172,175)$. Indeed, activated $\mathrm{T}$ cells within the inflammatory microenvironment, including Th17, selectively downregulate membrane-bound IL-6R expression via protease-mediated shedding, associated with increased sIL-6R levels $(175,179)$. Thus, local regulation of activated $\mathrm{T}$ cell responses to IL-6 critically rely on sIL-6R and IL-6 trans-signalling, which was shown to promote the maintenance of IL-17-secreting CD4 ${ }^{+} \mathrm{T}$ cells at the site of inflammation (175).

\section{STAT3 ENTERS THE GAME}

Being STAT3 the main mediator of IL-6 responses, its involvement in Th17 cells differentiation was predictable. Indeed, it was shown that differentiation of Th17 cells in response to IL-6 and TGFbeta did not require either STAT4 or STAT6, the leading transcription factors regulating Th1 and Th2 responses, but involved STAT3 activation instead. Th17 cells differentiation was abrogated in the absence of STAT3 both in vitro and in vivo $(180,181)$. Overexpression of a constitutively active form of STAT3, STAT3C, resulted in greatly increased numbers of IL-17 producing cells and enhanced expression of RORgammat in in vitro differentiated $\mathrm{CD}^{+}$lymphocytes (182). Moreover, STAT3 depletion in haematopoietic stem cells or specifically in $\mathrm{CD}^{+}$lymphocytes resulted in dramatic reduction in the number of Th17 lymphocytes (182, 183). Additionally, 
the STAT3 negative regulator SOCS3 also counteracts Th17 differentiation, as SOCS3 deficient mice showed enhanced Th17 cells generation associated with widespread auto-immune disease (184).

The role of STAT3 in Th17 cells appears to go beyond it simply mediating IL-6-triggered differentiation, since this factor is activated also by IL-23, which is required for amplification and maintenance of Th17 responses, and by IL-21, which also contributes to Th17 differentiation $(184,185)$. After the initial finding that STAT3 directly activates transcription from the $I l-17 \mathrm{~A}$ and $I l-17 F$ gene promoters (186), it was recently shown that STAT3 binds to and regulates multiple other key genes involved in Th17 cell differentiation, activation, proliferation and survival such as Rorgammat, Roralpha, Batf, Irf4, Ahr, IlGralpha and c-maf (187). The contribution of STAT3 to Th17 differentiation is balanced by STAT5, as the two factors can bind to the same DNA motif in the II-17 locus. IL-2-activated STAT5 can displace STAT3 from the Il-17 promoter, and recruits the transcriptional repressor NCoR2 (37). Accordingly, IL-2 deficiency leads to enhanced in vitro and in vivo IL-17 production, suggesting that Th17 differentiation depends on the relative concentrations of IL-2 and IL- 6 and on the consequent balance between activated STAT3 and STAT5 (188). The role of STAT3 in Th17 differentiation also in humans is highlighted by the observation that patients with hyper-immunoglobulin E syndrome (HIES), who show stat3 inactivating mutations (189, 190), display impaired Th17 differentiation $(191,192)$. This may explain the recurrent infections characteristic of the disease.

Additionally, STAT3 is known to contribute to T cell pathogenicity by regulating T cells expansion and homeostasis during inflammation. Indeed, STAT3 was shown to activate anti-apoptotic and pro-proliferative genes such as Bcl2, Jun and Fos, and to inhibit Tregs conversion downstream of IL-6 and IL-23 signalling (187). The role of STAT3 in Tregs biology is however not straightforward. While independent data confirm that the IL-6-STAT3 axis suppresses initial Treg differentiation, which is instead driven by TGFbeta alone, several lines of evidence suggest that STAT3 is however required for optimal Tregs activity (193). Indeed, Treg-specific STAT3 deletion leads to uncontrolled Th17 expansion and fatal Th17-dependent intestinal inflammation, even though Treg numbers were unaltered (194). STAT3 was indeed required for the expression of about $20 \%$ of the Foxp3 target genes, including $I l-10$ and $I l-35$. Failure of STAT3-deficient Tregs to properly respond to IL-10, specifically impaired their ability to suppress Th17-mediated inflammation (195). Moreover, STAT3 triggered repression of the IL-6 and TGFbeta genes by recruiting Foxp3 to their promoters. These observations are in line with those of Kortylewski and colleagues, who showed that STAT3-dependent IL-23 production by tumour infiltrating macrophages enhanced Foxp3 and IL-10 expression in Tregs via STAT3 activation (196).

\section{IL-6, TH17 AND STAT3: THE HOLY TRINITY IN AUTO-IMMUNITY?}

The role of STAT3 in Th17 differentiation implicates its involvement in auto-immune disorders, as also suggested by the identification of polymorphisms associated with greater risk of auto-immune disease (197). STAT3 is activated in synovial lining cells and in freshly isolated SF from RA patients (198), and patient's SF transduced with a dominant negative form of STAT3 undergo apoptosis and growth arrest (199). STAT3 may promote SF survival by opposing the proapoptotic effects delivered by EGF and STAT1 and by maintaining myc expression (199).

Several studies in animal models support the idea that the IL-6/IL-17/STAT3 loop is a key factor in regulating autoimmunity. Two different knock-in mouse strains have been generated mutating the tyrosine residue of gp130 involved in recruiting both SOCS3 and SHP2, Y757 in the mouse and Y759 in humans $(200,201)$. While Ohtani et al. generated a mutant allele carrying the human intracytoplasmic portion of gp130, and designated their strain gp130 directly introduced the $\mathrm{Y}$ to $\mathrm{F}$ point mutation in the mouse sequence, denominating their strain gp $130^{\mathrm{Y} 757 / \mathrm{Y} 757}$ (201). Both mutant strains lack SOCS3-mediated negative feedback, thus displaying enhanced gp130-mediated STAT3 activation. Lack of SHP2 recruitment, in addition, leads to impaired activation of the extracellular signal-regulated kinase/mitogen-activated protein kinase (ERK/MAPK) pathway. Different phenotypes were described for the two strains. While gp130 $13759 / \mathrm{F} 759$ mice undergo a spontaneous lymphocyte-mediated rheumatoid arthritis-like joint disease (202), gp130 ${ }^{\mathrm{Y} 757 / \mathrm{Y} 757}$ mice develop gastric tumours (203). The reasons for this difference are presently unknown and may relate to slight variations in signalling sensitivity (204). Arthritis in the gp $130^{\mathrm{F} 759 / \mathrm{F} 759}$ mice is characterized by high serum levels of IL-17, IL-6 and sIL-6R and by increased numbers of Th17 cells in the spleen and lymph nodes $(180,205)$. Disease development is dependent on both IL-17 and IL-6, since it is strongly reduced in $\mathrm{gp} 130^{\mathrm{F} 759 / \mathrm{F} 759}$ mice where the $I l-17 \mathrm{~A}$ or $I l-6$ genes were inactivated (172). Moreover, it could be shown that IL-6 functions are required also downstream of IL-17, since arthritis in IL-1 $7^{-/}$F759 mice could be rescued by IL-6 expression while IL-17 could not trigger disease development in the IL- $6^{-1-}$ F759 mice. Finally, specific deletion of STAT3 in type I collagen fibroblasts suppressed arthritis development, arguing for a crucial role of this factor in cells of the local stroma (205), and suggesting that hyper-STAT3 activity rather than impaired MAPK activation is responsible for the observed phenotype. IL-17 and IL-6 appear therefore to participate to a positive feedback loop as depicted in Figure 2, where STAT3 drives naïve T cells to differentiate into Th17 lymphocytes, which in turn produce IL-17 thus stimulating stromal cells to express and secrete IL-6. This was shown to require the activity of both STAT3 and NF-kB (205). IL-6 production in turn, in combination with TGFbeta, leads to increased STAT3-dependent Th17 differentiation and, in association with soluble IL-6R, acts on stromal cells to induce the secretion of pro-inflammatory chemokines. As already mentioned, IL-6R expression is cell type-restricted. Stromal cells are typically devoid of the membrane-bound IL-6R form, and must therefore rely on trans-signalling for IL-6 responses (59). Finally, IL-6-induced chemokines recruit immune cells that, producing IL-23, sustain Th17 cells survival and increase inflammation. Dysregulation of this pathway is likely involved in other auto-immune diseases, as it was already shown for EAE (205). 
Accordingly, in vivo inhibition of the gp130-associated JAK1 and JAK2 can ameliorate CIA in mice and AIA in rats, leading to a reduced expression of pathogenic cytokines including IL-6, IL-17 and IL-23 and to reduced Th1/Th17 cell numbers (206). On the other hand, IFNbeta $\square$ treatment improved EAE symptoms, down-regulating the Th17 response via decreased STAT3 and increased STAT1 phosphorylation in $\mathrm{CD}^{+} \mathrm{T}$ cells (207). This may in part explain the efficacy of IFNbeta therapy in MS patients (208). Finally, it was recently reported that p53-null CD45.1 mice develop kidney auto-immunity, characterized by increased Th17 cell numbers in the lymph nodes and increased serum IL-17 and IL-6 levels. This correlated with enhanced STAT3 phosphorylation following IL-6 stimulation of T lymphocytes (209). Interestingly, the STAT3 inhibitor S3I (210) suppressed Th17 cells expansion and alleviated the auto-immune disease.

\section{THE IL-6-IL-17-STAT3 LOOP IN INFLAMMATION-DRIVEN TUMOURIGENESIS}

It is well recognized that the microenvironment of chronic inflammation represents a tumour-predisposing niche, where both tumour initiation and promotion of resident cells can be triggered by means of different mechanisms. In particular, continuous exposure to reactive oxygen species (ROS) may cause genetic mutations, and cytokines and chemokines can induce epigenetic mutations and activate transcription factors such as STAT3 and NF-kB. These are constitutively activated in most tumours as a consequence of chronic signalling from upstream receptors and oncogenes (211), and in turn act in a coordinated way to enhance survival, proliferation, angiogenesis and invasions, promoting survival of initially transformed cells as well as tumour growth and metastasis (212). Moreover, virtually all solid tumours cause chronic inflammation of their microenvironment that likely contributes to tumour expansion and growth even for those tumours where no proven cause-relationship exists (213).

In addition to persistent infections with several microbial agents, which are associated with the development of gastric cancer, hepatocellular carcinoma, bladder or colon cancer, another leading cause of chronic inflammation is dysregulation of the immune responses and auto-immunity. An outstanding example is inflammatory bowel disease (IBD), which is associated with highly increased risk of developing colorectal cancer (214). By no means, however, do all chronic inflammatory or auto-immune conditions increase cancer risk, although the reasons for this are not yet understood. IL-6, which in association with TNFalpha and IL-1beta can sustain chronic inflammation, is one of the major factors involved in these processes mainly through STAT3 signalling (213). For example, intestinal levels of IL-6 and sIL-6R are elevated in IBD patients, correlating with clinical activity $(215,216)$. Serum IL-6 levels are elevated in many types of human cancers, and the IL-6 signalling cascade represents an attractive therapeutic target in cancer $(217,218)$. Indeed, IL-6 deficiency or specific STAT3 ablation in the colon epithelium blocks the induction and growth of colitis-associated cancer (219), and blockage of IL-6 trans-signalling suppresses the development of colitis-associated premalignant cancer in both the AOM and DSS models $(16,220)$ as well as enhancing the sensitivity of ovarian tumours to chemotherapy (221).

Even though the role of IL-17 in cancer is still controversial, a number of recent publications suggest that Th17 cells and IL-17 may also enter the picture. The role of Th17 cells may vary according to tumour type, since the presence of Th17 cells in human tumours has been associated with both bad and good prognosis $(222,223)$. Ovarian cancers, which are highly inflammatory and where IL-6 production and STAT3 are considered to play a major role (224), have been shown to contain high percentages of Th17 cells, and ovary tumour cells produce high amounts of IL-6 and TGFbeta, among other cytokines (222). Two reports suggest an anti-tumoural role of Th17 responses, describing increased tumour growth of lung metastasis and higher susceptibility to lung melanoma in IL-17A-deficient mice $(225,226)$. However, xenografts of different kind of tumoural cells (melanoma, bladder cancer, lymphoma, prostate cancer) have been shown to grow poorly in IL-17 or IL-17R-deficient mice $(227,228)$, and more efficiently in IFNgamma or IFNgammaR mutant mice. IL-17 produced by intra-tumour CD4 ${ }^{+} \mathrm{T}$ lymphocytes stimulates IL-6 production by both tumour and stromal cells, thus enhancing constitutive STAT3 activation and tumour cells survival, proliferation and angiogenesis (227). Finally, IL-17-deficient mice are strongly protected from DMBA/TPA-induced skin cancer (229), correlating with decreased IL-6 production and STAT3 phosphorylation in the tumour microenvironment, decreased expression of STAT3-regulated chemokines and consequent reduced infiltration of myeloid cells. Of note, this model of skin cancer is known to be completely STAT3-dependent (230). In contrast, in spite of increased expression of IL-17-related factors in gp $130^{\mathrm{Y} 757 / \mathrm{Y} 757}$ mice, IL-17A ablation in these mice does not alter the onset or development of gastric tumours, suggesting independence from Th17 lymphocytes. Accordingly, IL-17A expression is not up-regulated in gastric cancer (231).

Taken together, these data suggest that a feed forward loop between IL-6, IL-17 and STAT3 similar to the one described above and depicted in Figure 2 for auto-immunity may well play an important role in at least a subset of inflammation-driven tumours.

\section{CONCLUSIONS}

IL-17, IL-6 and STAT3 appear to be strictly functionally linked, such that aberrant up-regulation of one member leads to dysregulated activity of the others in a circular positive feedback loop, and this chronic dysregulation appears to be of paramount importance in the development of both auto-immune disorders and cancer. Indeed, IL-6 neutralizing antibodies have already been approved for the treatment of rheumatoid arthritis and tested for several other auto-immune disorders (62), and are 
likewise being tested for the treatment of human cancers (reviewed in (232)). In the light of the above considerations, combined therapeutic approaches hitting multiple players in the game may be a desirable strategy for both kinds of diseases.

\section{AKNOWLEDGMENTS}

Work in the author's laboratory was supported by grants to V.P. from the Italian Cancer Research Association (AIRC) and the Italian Ministry of University (MIUR and FIRB).

\section{REFERENCES}

1. O Dienz and M Rincon: The effects of IL-6 on CD4 T cell responses. Clin Immunol, 130(1), 27-33 (2009)

2. J Gauldie, DN Sauder, K. P. McAdam and C. A. Dinarello: Purified interleukin-1 (IL-1) from human monocytes stimulates acute-phase protein synthesis by rodent hepatocytes in vitro. Immunology, 60(2), 203-7 (1987)

3. E Fattori, M Cappelletti, P Costa, C Sellitto, L Cantoni, M Carelli, R Faggioni, G Fantuzzi, P Ghezzi and V Poli: Defective inflammatory response in interleukin 6-deficient mice. J Exp Med, 180(4), 1243-50 (1994)

4. T Hirano: Interleukin 6 in auto-immune and inflammatory diseases: a personal memoir. Proc Jpn Acad Ser B Phys Biol Sci, 86(7), 717-30 (2010)

5. PC Heinrich, I Behrmann, S Haan, HM Hermanns, G Muller-Newen and F Schaper: Principles of interleukin (IL)-6-type cytokine signalling and its regulation. Biochem J, 374(Pt 1), 1-20 (2003)

6. I Behrmann, HM Hermanns, C Haan, M Kortylewski, S Radtke, J Greiser and PC Heinrich: Signalling of interleukin-6 type cytokines via gp130, leukemia inhibitory factor (LIF) receptor and oncostatin M receptor. Eur Cytokine Netw, 11(3), 491-2 (2000)

7. N Fasnacht and W Muller: Conditional gp130 deficient mouse mutants. Semin Cell Dev Biol, 19(4), 379-84 (2008)

8. S Rose-John, J Scheller, G Elson and SA Jones: Interleukin-6 biology is coordinated by membrane-bound and soluble receptors: role in inflammation and cancer. J Leukoc Biol, 80(2), 227-36 (2006)

9. V Matthews, B Schuster, S Schutze, I Bussmeyer, A Ludwig, C Hundhausen, T Sadowski, P Saftig, D Hartmann, KJ Kallen and S Rose-John: Cellular cholesterol depletion triggers shedding of the human interleukin-6 receptor by ADAM10 and ADAM17 (TACE). J Biol Chem, 278(40), 38829-39 (2003)

10. SA Jones, S Horiuchi, N Topley, N Yamamoto and GM Fuller: The soluble interleukin 6 receptor: mechanisms of production and implications in disease. FASEB J, 15(1), 43-58 (2001)

11. R Atreya, J Mudter, S Finotto, J Mullberg, T Jostock, S Wirtz, M Schutz, B Bartsch, M Holtmann, C Becker, D Strand, J Czaja, JF Schlaak, HA Lehr, F Autschbach, G Schurmann, N Nishimoto, K Yoshizaki, H Ito, T Kishimoto, PR Galle, S RoseJohn and MF Neurath: Blockade of interleukin 6 trans signalling suppresses T-cell resistance against apoptosis in chronic intestinal inflammation: evidence in crohn disease and experimental colitis in vivo. Nat Med, 6(5), 583-8 (2000)

12. SM Hurst, TS Wilkinson, RM McLoughlin, S Jones, S Horiuchi, N Yamamoto, S Rose-John, GM Fuller, N Topley and SA Jones: IL-6 and its soluble receptor orchestrate a temporal switch in the pattern of leukocyte recruitment seen during acute inflammation. Immunity, 14(6), 705-14 (2001)

13. MA Nowell, PJ Richards, S Horiuchi, N Yamamoto, S Rose-John, N Topley, AS Williams and SA Jones: Soluble IL-6 receptor governs IL-6 activity in experimental arthritis: blockade of arthritis severity by soluble glycoprotein 130 . J Immunol, $171(6), 3202-9(2003)$

14. Q Chen, DT Fisher, KA Clancy, JM Gauguet, WC Wang, E Unger, S Rose-John, UH von Andrian, H Baumann and SS Evans: Fever-range thermal stress promotes lymphocyte trafficking across high endothelial venules via an interleukin 6 transsignalling mechanism. Nat Immunol, 7(12), 1299-308 (2006)

15. SJ Curnow, D Scheel-Toellner, W Jenkinson, K Raza, OM Durrani, JM Faint, S Rauz, K Wloka, D Pilling, S Rose-John, CD Buckley, PI Murray and M Salmon: Inhibition of T cell apoptosis in the aqueous humor of patients with uveitis by IL-6/soluble IL-6 receptor trans-signalling. J Immunol, 173(8), 5290-7 (2004) 
16. C Becker, MC Fantini, C Schramm, HA Lehr, S Wirtz, A Nikolaev, J Burg, S Strand, R Kiesslich, S Huber, H Ito, N Nishimoto, K Yoshizaki, T Kishimoto, PR Galle, M Blessing, S Rose-John and MF Neurath: TGF-beta suppresses tumor progression in colon cancer by inhibition of IL-6 trans-signalling. Immunity, 21(4), 491-501 (2004)

17. SA Jones: Directing transition from innate to acquired immunity: defining a role for IL-6. J Immunol, 175(6), 3463-8 (2005)

18. A Chalaris, B Rabe, K Paliga, H Lange, T Laskay, CA Fielding, SA Jones, S Rose-John and J Scheller: Apoptosis is a natural stimulus of IL6R shedding and contributes to the proinflammatory trans-signalling function of neutrophils. Blood, 110(6), 174855 (2007)

19. M Romano, M Sironi, C Toniatti, N Polentarutti, P Fruscella, P Ghezzi, R Faggioni, W Luini, V van Hinsbergh, S Sozzani, F Bussolino, V Poli, G Ciliberto and A Mantovani: Role of IL-6 and its soluble receptor in induction of chemokines and leukocyte recruitment. Immunity, 6(3), 315-25 (1997)

20. C Gerhartz, B Heesel, J Sasse, U Hemmann, C Landgraf, J Schneider-Mergener, F Horn, PC Heinrich and L Graeve: Differential activation of acute phase response factor/STAT3 and STAT1 via the cytoplasmic domain of the interleukin 6 signal transducer gp130. I. Definition of a novel phosphotyrosine motif mediating STAT1 activation. J Biol Chem, 271(22), 12991-8 (1996)

21. J Schmitz, H Dahmen, C Grimm, C Gendo, G Muller-Newen, PC Heinrich and F Schaper: The cytoplasmic tyrosine motifs in full-length glycoprotein 130 have different roles in IL-6 signal transduction. J Immunol, 164(2), 848-54 (2000)

22. T Hirano, K Nakajima and M Hibi: Signalling mechanisms through gp130: a model of the cytokine system. Cytokine Growth Factor Rev, 8(4), 241-52 (1997)

23. J Schmitz, M Weissenbach, S Haan, PC Heinrich and F Schaper: SOCS3 exerts its inhibitory function on interleukin-6 signal transduction through the SHP2 recruitment site of gp130. J Biol Chem, 275(17), 12848-56 (2000)

24. C Schindler, DE Levy and T Decker: JAK-STAT signalling: from interferons to cytokines. J Biol Chem, 282(28), 20059-63 (2007)

25. BB Aggarwal, AB Kunnumakkara, KB Harikumar, SR Gupta, ST Tharakan, C Koca, S Dey and B Sung: Signal transducer and activator of transcription-3, inflammation, and cancer: how intimate is the relationship? Ann N Y Acad Sci, 1171, 59-76 (2009)

26. M Kortylewski, R Jove and H Yu: Targeting STAT3 affects melanoma on multiple fronts. Cancer Metastasis Rev, 24(2), 315-27 (2005)

27. J Turkson and R Jove: STAT proteins: novel molecular targets for cancer drug discovery. Oncogene, 19(56), 6613-26 (2000)

28. K Siddiquee, S Zhang, WC Guida, MA Blaskovich, B Greedy, HR Lawrence, ML Yip, R Jove, MM McLaughlin, NJ Lawrence, SM Sebti and J Turkson: Selective chemical probe inhibitor of Stat3, identified through structure-based virtual screening, induces antitumor activity. Proc Natl Acad Sci U S A, 104(18), 7391-6 (2007)

29. CL Yu, DJ Meyer, GS Campbell, AC Larner, C Carter-Su, J Schwartz and R Jove: Enhanced DNA-binding activity of a Stat3-related protein in cells transformed by the Src oncoprotein. Science, 269(5220), 81-3 (1995)

30. UM Wegenka, J Buschmann, C Lutticken, PC Heinrich and F Horn: Acute-phase response factor, a nuclear factor binding to acute-phase response elements, is rapidly activated by interleukin-6 at the posttranslational level. Mol Cell Biol, 13(1), 276-88 (1993)

31. UM Wegenka, C Lutticken, J Buschmann, J Yuan, F Lottspeich, W Muller-Esterl, C Schindler, E Roeb, PC Heinrich and F Horn: The interleukin-6-activated acute-phase response factor is antigenically and functionally related to members of the signal transducer and activator of transcription (STAT) family. Mol Cell Biol, 14(5), 3186-96 (1994)

32. S Akira, Y Nishio, M Inoue, XJ Wang, S Wei, T Matsusaka, K Yoshida, T Sudo, M Naruto and T Kishimoto: Molecular cloning of APRF, a novel IFN-stimulated gene factor 3 p91-related transcription factor involved in the gp130-mediated signalling pathway. Cell, 77(1), 63-71 (1994)

33. Z Zhong, Z Wen and JE Darnell, Jr: Stat3: a STAT family member activated by tyrosine phosphorylation in response to epidermal growth factor and interleukin-6. Science, 264(5155), 95-8 (1994) 
34. F Vallania, D Schiavone, S Dewilde, E Pupo, S Garbay, R Calogero, M Pontoglio, P Provero and V Poli: Genome-wide discovery of functional transcription factor binding sites by comparative genomics: the case of Stat3. Proc Natl Acad Sci U S A, 106(13), 5117-22 (2009)

35. S Giraud, F Bienvenu, S Avril, H Gascan, DM Heery and O Coqueret: Functional interaction of STAT3 transcription factor with the coactivator NcoA/SRC1a. J Biol Chem, 277(10), 8004-11 (2002)

36. C Zugowski, F Lieder, A Muller, J Gasch, FM Corvinus, R Moriggl and K Friedrich: STAT3 controls matrix metalloproteinase-1 expression in colon carcinoma cells by both direct and AP-1-mediated interaction with the MMP-1 promoter. Biol Chem, 392(5), 449-59 (2011)

37. XP Yang, K Ghoreschi, SM Steward-Tharp, J Rodriguez-Canales, J Zhu, JR Grainger, K Hirahara, HW Sun, L Wei, G Vahedi, Y Kanno, JJ O'Shea and A Laurence: Opposing regulation of the locus encoding IL-17 through direct, reciprocal actions of STAT3 and STAT5. Nat Immunol, 12(3), 247-54 (2011)

38. F De Miguel, SO Lee, SA Onate and AC Gao: Stat3 enhances transactivation of steroid hormone receptors. Nucl Recept, $1(1), 3(2003)$

39. S Ray, I Boldogh and AR Brasier: STAT3 NH2-terminal acetylation is activated by the hepatic acute-phase response and required for IL-6 induction of angiotensinogen. Gastroenterology, 129(5), 1616-32 (2005)

40. E Caldenhoven, TB van Dijk, R Solari, J Armstrong, JA Raaijmakers, JW Lammers, L Koenderman and RP de Groot: STAT3beta, a splice variant of transcription factor STAT3, is a dominant negative regulator of transcription. J Biol Chem, 271(22), 13221-7 (1996)

41. TS Schaefer, LK Sanders and D Nathans: Cooperative transcriptional activity of Jun and Stat3 beta, a short form of Stat3. Proc Natl Acad Sci U S A, 92(20), 9097-101 (1995)

42. JY Yoo, DL Huso, D Nathans and S Desiderio: Specific ablation of Stat3beta distorts the pattern of Stat3-responsive gene expression and impairs recovery from endotoxic shock. Cell, 108(3), 331-44 (2002)

43. SE Baranzini: The genetics of auto-immune diseases: a networked perspective. Curr Opin Immunol, 21(6), 596-605 (2009)

44. MB Oldstone: Molecular mimicry and immune-mediated diseases. FASEB J, 12(13), 1255-65 (1998)

45. GF Ferraccioli and E Gremese: Biological therapies in auto-immune chronic inflammatory diseases (ACIDs). Eur Rev Med Pharmacol Sci, 10(1), 37-40 (2006)

46. A Kimura and T Kishimoto: Th17 cells in inflammation. Int Immunopharmacol, 11(3), 319-22 (2011)

47. KK Hoyer, H Dooms, L Barron and AK Abbas: Interleukin-2 in the development and control of inflammatory disease. Immunol Rev, 226, 19-28 (2008)

48. JJ O'Shea, A Ma and P Lipsky: Cytokines and auto-immunity. Nat Rev Immunol, 2(1), 37-45 (2002)

49. GS Firestein: Evolving concepts of rheumatoid arthritis. Nature, 423(6937), 356-61 (2003)

50. U Muller-Ladner, RE Gay and S Gay: Molecular biology of cartilage and bone destruction. Curr Opin Rheumatol, 10(3), 212-9 (1998)

51. M Feldmann, FM Brennan and RN Maini: Role of cytokines in rheumatoid arthritis. Annu Rev Immunol, 14, 397-440 (1996)

52. N Milman, J Karsh and RA Booth: Correlation of a multi-cytokine panel with clinical disease activity in patients with rheumatoid arthritis. Clin Biochem, 43(16-17), 1309-14 (2010)

53. FA Houssiau and BR Lauwerys: Immunotherapeutic approaches of rheumatic disorders. Acta Clin Belg, 53(3), 155-61 (1998)

54. F de Benedetti, M Massa, P Robbioni, A Ravelli, GR Burgio and A Martini: Correlation of serum interleukin-6 levels with joint involvement and thrombocytosis in systemic juvenile rheumatoid arthritis. Arthritis Rheum, 34(9), 1158-63 (1991) 
55. T Hirano, T Matsuda, M Turner, N Miyasaka, G Buchan, B Tang, K Sato, M Shimizu, R Maini, M Feldmann and et al.: Excessive production of interleukin 6/B cell stimulatory factor-2 in rheumatoid arthritis. Eur J Immunol, 18(11), 1797-801 (1988)

56. S Kotake, K Sato, KJ Kim, N Takahashi, N Udagawa, I Nakamura, A Yamaguchi, T Kishimoto, T Suda and S Kashiwazaki: Interleukin- 6 and soluble interleukin- 6 receptors in the synovial fluids from rheumatoid arthritis patients are responsible for osteoclast-like cell formation. J Bone Miner Res, 11(1), 88-95 (1996)

57. T Tamura, N Udagawa, N Takahashi, C Miyaura, S Tanaka, Y Yamada, Y Koishihara, Y Ohsugi, K Kumaki, T Taga and et al.: Soluble interleukin-6 receptor triggers osteoclast formation by interleukin 6. Proc Natl Acad Sci U S A, 90(24), 11924-8 (1993)

58. B Bartok and GS Firestein: Fibroblast-like synoviocytes: key effector cells in rheumatoid arthritis. Immunol Rev, 233(1), 233-55 (2010)

59. T Taga: IL6 signalling through IL6 receptor and receptor-associated signal transducer, gp130. Res Immunol, 143(7), 737-9 (1992)

60. M Mihara, Y Moriya, T Kishimoto and Y Ohsugi: Interleukin-6 (IL-6) induces the proliferation of synovial fibroblastic cells in the presence of soluble IL-6 receptor. Br J Rheumatol, 34(4), 321-5 (1995)

61. N Nishimoto, A Ito, M Ono, H Tagoh, T Matsumoto, T Tomita, T Ochi and K Yoshizaki: IL-6 inhibits the proliferation of fibroblastic synovial cells from rheumatoid arthritis patients in the presence of soluble IL-6 receptor. Int Immunol, 12(2), 187-93 (2000)

62. T Tanaka, M Narazaki and T Kishimoto: Anti-interleukin-6 receptor antibody, tocilizumab, for the treatment of auto-immune diseases. FEBS Lett (2011)

63. PP Tak, WF Rigby, A Rubbert-Roth, CG Peterfy, RF van Vollenhoven, W Stohl, E Hessey, A Chen, H Tyrrell and TM Shaw: Inhibition of joint damage and improved clinical outcomes with rituximab plus methotrexate in early active rheumatoid arthritis: the IMAGE trial. Ann Rheum Dis, 70(1), 39-46 (2011)

64. DE Trentham, AS Townes and AH Kang: Auto-immunity to type II collagen an experimental model of arthritis. J Exp Med, $146(3), 857-68$ (1977)

65. D Brackertz, GF Mitchell and IR Mackay: Antigen-induced arthritis in mice. I. Induction of arthritis in various strains of mice. Arthritis Rheum, 20(3), 841-50 (1977)

66. EC Keystone, HU Schorlemmer, C Pope and AC Allison: Zymosan-induced arthritis: a model of chronic proliferative arthritis following activation of the alternative pathway of complement. Arthritis Rheum, 20(7), 1396-1401 (1977)

67. T Alonzi, E Fattori, D Lazzaro, P Costa, L Probert, G Kollias, F De Benedetti, V Poli and G Ciliberto: Interleukin 6 is required for the development of collagen-induced arthritis. J Exp Med, 187(4), 461-8 (1998)

68. M Sasai, Y Saeki, S Ohshima, K Nishioka, T Mima, T Tanaka, Y Katada, K Yoshizaki, M Suemura and T Kishimoto: Delayed onset and reduced severity of collagen-induced arthritis in interleukin-6-deficient mice. Arthritis Rheum, 42(8), 163543 (1999)

69. S Ohshima, Y Saeki, T Mima, M Sasai, K Nishioka, S Nomura, M Kopf, Y Katada, T Tanaka, M Suemura and T Kishimoto: Interleukin 6 plays a key role in the development of antigen-induced arthritis. Proc Natl Acad Sci U S A, 95(14), 8222-6 (1998)

70. A Boe, M Baiocchi, M Carbonatto, R Papoian and O Serlupi-Crescenzi: Interleukin 6 knock-out mice are resistant to antigeninduced experimental arthritis. Cytokine, 11(12), 1057-64 (1999)

71. H Kobayashi, S Ohshima, K Nishioka, N Yamaguchi, M Umeshita-Sasai, T Ishii, T Mima, T Kishimoto, I Kawase and Y Saeki: Antigen induced arthritis (AIA) can be transferred by bone marrow transplantation: evidence that interleukin 6 is essential for induction of AIA. J Rheumatol, 29(6), 1176-82 (2002)

72. FA van de Loo, S Kuiper, FH van Enckevort, OJ Arntz and WB van den Berg: Interleukin-6 reduces cartilage destruction during experimental arthritis. A study in interleukin-6-deficient mice. Am J Pathol, 151(1), 177-91 (1997) 
73. AS de Hooge, FA van De Loo, OJ Arntz and WB van Den Berg: Involvement of IL-6, apart from its role in immunity, in mediating a chronic response during experimental arthritis. Am J Pathol, 157(6), 2081-91 (2000)

74. AS de Hooge, FA van de Loo, MI Koenders, MB Bennink, OJ Arntz, T Kolbe and WB van den Berg: Local activation of STAT-1 and STAT-3 in the inflamed synovium during zymosan-induced arthritis: exacerbation of joint inflammation in STAT-1 gene-knockout mice. Arthritis Rheum, 50(6), 2014-23 (2004)

75. C Gabay: Interleukin-6 and chronic inflammation. Arthritis Res Ther, 8 Suppl 2, S3 (2006)

76. MI Gobbini, ME Smith, ND Richert, JA Frank and HF McFarland: Effect of open label pulse cyclophosphamide therapy on MRI measures of disease activity in five patients with refractory relapsing-remitting multiple sclerosis. J Neuroimmunol, 99(1), 142-9 (1999)

77. G Giovannoni, S Cook, K Rammohan, P Rieckmann, PS Sorensen, P Vermersch, A Hamlett, V Viglietta and S Greenberg: Sustained disease-activity-free status in patients with relapsing-remitting multiple sclerosis treated with cladribine tablets in the CLARITY study: a post-hoc and subgroup analysis. Lancet Neurol, 10(4), 329-37 (2011)

78. H Krapf, SP Morrissey, O Zenker, T Zwingers, R Gonsette and HP Hartung: Effect of mitoxantrone on MRI in progressive MS: results of the MIMS trial. Neurology, 65(5), 690-5 (2005)

79. K Frei, S Fredrikson, A Fontana and H Link: Interleukin-6 is elevated in plasma in multiple sclerosis. J Neuroimmunol, 31(2), 147-53 (1991)

80. D Maimone, S Gregory, BG Arnason and AT Reder: Cytokine levels in the cerebrospinal fluid and serum of patients with multiple sclerosis. J Neuroimmunol, 32(1), 67-74 (1991)

81. N Nishimoto, K Yoshizaki, N Eiraku, K Machigashira, H Tagoh, A Ogata, T Kuritani, M Osame and T Kishimoto: Elevated levels of interleukin-6 in serum and cerebrospinal fluid of HTLV-I-associated myelopathy/tropical spastic paraparesis. J Neurol Sci, 97(2-3), 183-93 (1990)

82. D Maimone, GC Guazzi and P Annunziata: IL-6 detection in multiple sclerosis brain. J Neurol Sci, 146(1), 59-65 (1997)

83. MN Woodroofe and ML Cuzner: Cytokine mRNA expression in inflammatory multiple sclerosis lesions: detection by nonradioactive in situ hybridization. Cytokine, 5(6), 583-8 (1993)

84. V Navikas, D Matusevicius, M Soderstrom, S Fredrikson, P Kivisakk, A Ljungdahl, B Hojeberg and H Link: Increased interleukin-6 mRNA expression in blood and cerebrospinal fluid mononuclear cells in multiple sclerosis. J Neuroimmunol, 64(1), 63-9 (1996)

85. N Kerlero de Rosbo, R Milo, MB Lees, D Burger, CC Bernard and A Ben-Nun: Reactivity to myelin antigens in multiple sclerosis. Peripheral blood lymphocytes respond predominantly to myelin oligodendrocyte glycoprotein. J Clin Invest, 92(6), 2602-8 (1993)

86. B Bielekova, MH Sung, N Kadom, R Simon, H McFarland and R Martin: Expansion and functional relevance of high-avidity myelin-specific CD4 ${ }^{+} \mathrm{T}$ cells in multiple sclerosis. J Immunol, 172(6), 3893-904 (2004)

87. I Mendel, N Kerlero de Rosbo and A Ben-Nun: A myelin oligodendrocyte glycoprotein peptide induces typical chronic experimental auto-immune encephalomyelitis in $\mathrm{H}-2 \mathrm{~b}$ mice: fine specificity and $\mathrm{T}$ cell receptor $\mathrm{V}$ beta expression of encephalitogenic T cells. Eur J Immunol, 25(7), 1951-9 (1995)

88. I Mendel, A Katz, N Kozak, A Ben-Nun and M Revel: Interleukin-6 functions in auto-immune encephalomyelitis: a study in gene-targeted mice. Eur J Immunol, 28(5), 1727-37 (1998)

89. HP Eugster, K Frei, M Kopf, H Lassmann and A Fontana: IL-6-deficient mice resist myelin oligodendrocyte glycoproteininduced auto-immune encephalomyelitis. Eur J Immunol, 28(7), 2178-87 (1998)

90. Y Okuda, S Sakoda, CC Bernard, H Fujimura, Y Saeki, T Kishimoto and T Yanagihara: IL-6-deficient mice are resistant to the induction of experimental auto-immune encephalomyelitis provoked by myelin oligodendrocyte glycoprotein. Int Immunol, 10(5), 703-8 (1998) 
91. Y Okuda, S Sakoda, H Fujimura, Y Saeki, T Kishimoto and T Yanagihara: IL-6 plays a crucial role in the induction phase of myelin oligodendrocyte glucoprotein 35-55 induced experimental auto-immune encephalomyelitis. J Neuroimmunol, 101(2), 188-96 (1999)

92. EB Samoilova, JL Horton, B Hilliard, TS Liu and Y Chen: IL-6-deficient mice are resistant to experimental auto-immune encephalomyelitis: roles of IL-6 in the activation and differentiation of autoreactive T cells. J Immunol, 161(12), 6480-6 (1998)

93. JL Baron, JA Madri, NH Ruddle, G Hashim and CA Janeway, Jr.: Surface expression of alpha 4 integrin by CD4 T cells is required for their entry into brain parenchyma. J Exp Med, 177(1), 57-68 (1993)

94. A Quintana, M Muller, RF Frausto, R Ramos, DR Getts, E Sanz, MJ Hofer, M Krauthausen, NJ King, J Hidalgo and IL Campbell: Site-specific production of IL-6 in the central nervous system retargets and enhances the inflammatory response in experimental auto-immune encephalomyelitis. J Immunol, 183(3), 2079-88 (2009)

95. HP Eugster, K Frei, F Winkler, U Koedel, W Pfister, H Lassmann and A Fontana: Superantigen overcomes resistance of IL6-deficient mice towards MOG-induced EAE by a TNFR1 controlled pathway. Eur J Immunol, 31(8), 2302-12 (2001)

96. IL Campbell, CR Abraham, E Masliah, P Kemper, JD Inglis, MB Oldstone and L Mucke: Neurologic disease induced in transgenic mice by cerebral overexpression of interleukin 6. Proc Natl Acad Sci U S A, 90(21), 10061-5 (1993)

97. A Frustaci, L Cuoco, C Chimenti, M Pieroni, G Fioravanti, N Gentiloni, A Maseri and G Gasbarrini: Celiac disease associated with auto-immune myocarditis. Circulation, 105(22), 2611-8 (2002)

98. EP Corssmit, MD Trip and JD Durrer: Loffler's endomyocarditis in the idiopathic hypereosinophilic syndrome. Cardiology, 91(4), 272-6 (1999)

99. B Hervier, A Masseau, C Bossard, C Agard and M Hamidou: Vasa-vasoritis of the aorta and fatal myocarditis in fulminant Churg-Strauss syndrome. Rheumatology (Oxford), 47(11), 1728-9 (2008)

100. K Fuse, M Kodama, Y Okura, M Ito, S Hirono, K Kato, H Hanawa and Y Aizawa: Predictors of disease course in patients with acute myocarditis. Circulation, 102(23), 2829-35 (2000)

101. M Nishii, T Inomata, H Takehana, I Takeuchi, H Nakano, T Koitabashi, J Nakahata, N Aoyama and T Izumi: Serum levels of interleukin-10 on admission as a prognostic predictor of human fulminant myocarditis. J Am Coll Cardiol, 44(6), 1292-7 (2004)

102. EI Grodums and G Dempster: Myocarditis in experimental Coxsackie B-3 infection. Can J Microbiol, 5, 605-15 (1959)

103. CL Pummerer, K Luze, G Grassl, K Bachmaier, F Offner, SK Burrell, DM Lenz, TJ Zamborelli, JM Penninger and N Neu: Identification of cardiac myosin peptides capable of inducing auto-immune myocarditis in BALB/c mice. J Clin Invest, 97(9), 2057-62 (1996)

104. K Bachmaier, C Pummerer, I Kozieradzki, K Pfeffer, TW Mak, N Neu and JM Penninger: Low-molecular-weight tumor necrosis factor receptor p55 controls induction of auto-immune heart disease. Circulation, 95(3), 655-61 (1997)

105. M Afanasyeva, Y Wang, Z Kaya, S Park, MJ Zilliox, BH Schofield, SL Hill and NR Rose: Experimental auto-immune myocarditis in A/J mice is an interleukin-4-dependent disease with a Th2 phenotype. Am J Pathol, 159(1), 193-203 (2001)

106. M Afanasyeva, Y Wang, Z Kaya, EA Stafford, KM Dohmen, AA Sadighi Akha and NR Rose: Interleukin-12 receptor/STAT4 signalling is required for the development of auto-immune myocarditis in mice by an interferon-gammaindependent pathway. Circulation, 104(25), 3145-51 (2001)

107. U Eriksson, MO Kurrer, W Sebald, F Brombacher and M Kopf: Dual role of the IL-12/IFN-gamma axis in the development of auto-immune myocarditis: induction by IL-12 and protection by IFN-gamma. J Immunol, 167(9), 5464-9 (2001)

108. U Eriksson, MO Kurrer, R Bingisser, HP Eugster, P Saremaslani, F Follath, S Marsch and U Widmer: Lethal auto-immune myocarditis in interferon-gamma receptor-deficient mice: enhanced disease severity by impaired inducible nitric oxide synthase induction. Circulation, 103(1), 18-21 (2001)

109. U Eriksson, MO Kurrer, N Schmitz, SC Marsch, A Fontana, HP Eugster and M Kopf: Interleukin-6-deficient mice resist development of auto-immune myocarditis associated with impaired upregulation of complement $\mathrm{C} 3$. Circulation, 107(2), 320-5 (2003) 
110. J Zhu and WE Paul: Peripheral $\mathrm{CD}^{+}$T-cell differentiation regulated by networks of cytokines and transcription factors. Immunol Rev, 238(1), 247-62 (2010)

111. L Camoglio, AA de Velde, A de Boer, FJ ten Kate, M Kopf and SJ van Deventer: Hapten-induced colitis associated with maintained Th1 and inflammatory responses in IFN-gamma receptor-deficient mice. Eur J Immunol, 30(5), 1486-95 (2000)

112. IA Ferber, S Brocke, C Taylor-Edwards, W Ridgway, C Dinisco, L Steinman, D Dalton and CG Fathman: Mice with a disrupted IFN-gamma gene are susceptible to the induction of experimental auto-immune encephalomyelitis (EAE). J Immunol, 156(1), 5-7 (1996)

113. H Hata, N Sakaguchi, H Yoshitomi, Y Iwakura, K Sekikawa, Y Azuma, C Kanai, E Moriizumi, T Nomura, T Nakamura and S Sakaguchi: Distinct contribution of IL-6, TNF-alpha, IL-1, and IL-10 to T cell-mediated spontaneous auto-immune arthritis in mice. J Clin Invest, 114(4), 582-8 (2004)

114. K Hirota, M Hashimoto, H Yoshitomi, S Tanaka, T Nomura, T Yamaguchi, Y Iwakura, N Sakaguchi and S Sakaguchi: T cell self-reactivity forms a cytokine milieu for spontaneous development of $\mathrm{IL}_{-1} 7^{+}$Th cells that cause auto-immune arthritis. $\mathrm{J}$ Exp Med, 204(1), 41-7 (2007)

115. DO Willenborg, S Fordham, CC Bernard, WB Cowden and IA Ramshaw: IFN-gamma plays a critical down-regulatory role in the induction and effector phase of myelin oligodendrocyte glycoprotein-induced auto-immune encephalomyelitis. J Immunol, 157(8), 3223-7 (1996)

116. GX Zhang, S Yu, B Gran, J Li, I Siglienti, X Chen, D Calida, E Ventura, M Kamoun and A Rostami: Role of IL-12 receptor beta 1 in regulation of T cell response by APC in experimental auto-immune encephalomyelitis. J Immunol, 171(9), 4485-92 (2003)

117. B Becher, BG Durell and RJ Noelle: Experimental auto-immune encephalitis and inflammation in the absence of interleukin-12. J Clin Invest, 110(4), 493-7 (2002)

118. B Gran, GX Zhang, S Yu, J Li, XH Chen, ES Ventura, M Kamoun and A Rostami: IL-12p35-deficient mice are susceptible to experimental auto-immune encephalomyelitis: evidence for redundancy in the IL-12 system in the induction of central nervous system auto-immune demyelination. J Immunol, 169(12), 7104-10 (2002)

119. LE Harrington, RD Hatton, PR Mangan, H Turner, TL Murphy, KM Murphy and CT Weaver: Interleukin 17-producing $\mathrm{CD}^{+}$effector $\mathrm{T}$ cells develop via a lineage distinct from the $\mathrm{T}$ helper type 1 and 2 lineages. Nat Immunol, 6(11), 1123-32 (2005)

120. H Park, Z Li, XO Yang, SH Chang, R Nurieva, YH Wang, Y Wang, L Hood, Z Zhu, Q Tian and C Dong: A distinct lineage of CD4 T cells regulates tissue inflammation by producing interleukin 17. Nat Immunol, 6(11), 1133-41 (2005)

121. XY Cai, CP Gommoll, Jr., L Justice, SK Narula and JS Fine: Regulation of granulocyte colony-stimulating factor gene expression by interleukin-17. Immunol Lett, 62(1), 51-8 (1998)

122. F Fossiez, O Djossou, P Chomarat, L Flores-Romo, S Ait-Yahia, C Maat, JJ Pin, P Garrone, E Garcia, S Saeland, D Blanchard, C Gaillard, B Das Mahapatra, E Rouvier, P Golstein, J Banchereau and S Lebecque: T cell interleukin-17 induces stromal cells to produce proinflammatory and hematopoietic cytokines. J Exp Med, 183(6), 2593-603 (1996)

123. M Laan, ZH Cui, H Hoshino, J Lotvall, M Sjostrand, DC Gruenert, BE Skoogh and A Linden: Neutrophil recruitment by human IL-17 via C-X-C chemokine release in the airways. J Immunol, 162(4), 2347-52 (1999)

124. C Albanesi, C Scarponi, A Cavani, M Federici, F Nasorri and G Girolomoni: Interleukin-17 is produced by both Th1 and Th2 lymphocytes, and modulates interferon-gamma- and interleukin-4-induced activation of human keratinocytes. J Invest Dermatol, 115(1), 81-7 (2000)

125. C Albanesi, A Cavani and G Girolomoni: IL-17 is produced by nickel-specific T lymphocytes and regulates ICAM-1 expression and chemokine production in human keratinocytes: synergistic or antagonist effects with IFN-gamma and TNF-alpha. J Immunol, 162(1), 494-502 (1999)

126. H Kebir, K Kreymborg, I Ifergan, A Dodelet-Devillers, R Cayrol, M Bernard, F Giuliani, N Arbour, B Becher and A Prat: Human TH17 lymphocytes promote blood-brain barrier disruption and central nervous system inflammation. Nat Med, 13(10), $1173-5$ (2007) 
127. C Lock, G Hermans, R Pedotti, A Brendolan, E Schadt, H Garren, A Langer-Gould, S Strober, B Cannella, J Allard, P Klonowski, A Austin, N Lad, N Kaminski, SJ Galli, JR Oksenberg, CS Raine, R Heller and L Steinman: Gene-microarray analysis of multiple sclerosis lesions yields new targets validated in auto-immune encephalomyelitis. Nat Med, 8(5), 500-8 (2002)

128. D Matusevicius, P Kivisakk, B He, N Kostulas, V Ozenci, S Fredrikson and H Link: Interleukin-17 mRNA expression in blood and CSF mononuclear cells is augmented in multiple sclerosis. Mult Scler, 5(2), 101-4 (1999)

129. S Kotake, N Udagawa, N Takahashi, K Matsuzaki, K Itoh, S Ishiyama, S Saito, K Inoue, N Kamatani, MT Gillespie, TJ Martin and T Suda: IL-17 in synovial fluids from patients with rheumatoid arthritis is a potent stimulator of osteoclastogenesis. J Clin Invest, 103(9), 1345-52 (1999)

130. K Sato, A Suematsu, K Okamoto, A Yamaguchi, Y Morishita, Y Kadono, S Tanaka, T Kodama, S Akira, Y Iwakura, DJ Cua and H Takayanagi: Th17 functions as an osteoclastogenic helper $\mathrm{T}$ cell subset that links $\mathrm{T}$ cell activation and bone destruction. J Exp Med, 203(12), 2673-82 (2006)

131. Y Komiyama, S Nakae, T Matsuki, A Nambu, H Ishigame, S Kakuta, K Sudo and Y Iwakura: IL-17 plays an important role in the development of experimental auto-immune encephalomyelitis. J Immunol, 177(1), 566-73 (2006)

132. B Afzali, G Lombardi, RI Lechler and GM Lord: The role of T helper 17 (Th17) and regulatory T cells (Treg) in human organ transplantation and auto-immune disease. Clin Exp Immunol, 148(1), 32-46 (2007)

133. S Nakae, A Nambu, K Sudo and Y Iwakura: Suppression of immune induction of collagen-induced arthritis in IL-17deficient mice. J Immunol, 171(11), 6173-7 (2003)

134. Ivanov, II, BS McKenzie, L Zhou, CE Tadokoro, A Lepelley, JJ Lafaille, DJ Cua and DR Littman: The orphan nuclear receptor RORgammat directs the differentiation program of proinflammatory IL-17 ${ }^{+}$T helper cells. Cell, 126(6), 1121-33 (2006)

135. M Rangachari, N Mauermann, RR Marty, S Dirnhofer, MO Kurrer, V Komnenovic, JM Penninger and U Eriksson: T-bet negatively regulates auto-immune myocarditis by suppressing local production of interleukin 17. J Exp Med, 203(8), 2009-19 (2006)

136. I Sonderegger, TA Rohn, MO Kurrer, G Iezzi, Y Zou, RA Kastelein, MF Bachmann and M Kopf: Neutralization of IL-17 by active vaccination inhibits IL-23-dependent auto-immune myocarditis. Eur J Immunol, 36(11), 2849-56 (2006)

137. GX Zhang, B Gran, S Yu, J Li, I Siglienti, X Chen, M Kamoun and A Rostami: Induction of experimental auto-immune encephalomyelitis in IL-12 receptor-beta 2-deficient mice: IL-12 responsiveness is not required in the pathogenesis of inflammatory demyelination in the central nervous system. J Immunol, 170(4), 2153-60 (2003)

138. CL Langrish, Y Chen, WM Blumenschein, J Mattson, B Basham, JD Sedgwick, T McClanahan, RA Kastelein and DJ Cua: IL-23 drives a pathogenic T cell population that induces auto-immune inflammation. J Exp Med, 201(2), 233-40 (2005)

139. M Veldhoen, RJ Hocking, CJ Atkins, RM Locksley and B Stockinger: TGFbeta in the context of an inflammatory cytokine milieu supports de novo differentiation of IL-17-producing T cells. Immunity, 24(2), 179-89 (2006)

140. H Haruta, N Ohguro, M Fujimoto, S Hohki, F Terabe, S Serada, S Nomura, K Nishida, T Kishimoto and T Naka: Blockade of interleukin-6 signalling suppresses not only th17 but also interphotoreceptor retinoid binding protein-specific Th1 by promoting regulatory T cells in experimental auto-immune uveoretinitis. Invest Ophthalmol Vis Sci, 52(6), 3264-71 (2011)

141. S Dominitzki, MC Fantini, C Neufert, A Nikolaev, PR Galle, J Scheller, G Monteleone, S Rose-John, MF Neurath and C Becker: Cutting edge: trans-signaling via the soluble IL-6R abrogates the induction of FoxP3 in naive CD4 $4^{+} \mathrm{CD} 25^{-} \mathrm{T}$ cells. J Immunol, 179(4), 2041-5 (2007)

142. E Bettelli, Y Carrier, W Gao, T Korn, TB Strom, M Oukka, HL Weiner and VK Kuchroo: Reciprocal developmental pathways for the generation of pathogenic effector TH17 and regulatory T cells. Nature, 441(7090), 235-8 (2006)

143. PR Mangan, LE Harrington, DB O'Quinn, WS Helms, DC Bullard, CO Elson, RD Hatton, SM Wahl, TR Schoeb and CT Weaver: Transforming growth factor-beta induces development of the T(H)17 lineage. Nature, 441(7090), 231-4 (2006)

144. MJ McGeachy, KS Bak-Jensen, Y Chen, CM Tato, W Blumenschein, T McClanahan and DJ Cua: TGF-beta and IL-6 drive the production of IL-17 and IL-10 by T cells and restrain T(H)-17 cell-mediated pathology. Nat Immunol, 8(12), 1390-7 (2007) 
145. F Annunziato, L Cosmi, V Santarlasci, L Maggi, F Liotta, B Mazzinghi, E Parente, L Fili, S Ferri, F Frosali, F Giudici, P Romagnani, P Parronchi, F Tonelli, E Maggi and S Romagnani: Phenotypic and functional features of human Th17 cells. J Exp Med, 204(8), 1849-61 (2007)

146. YK Lee, H Turner, CL Maynard, JR Oliver, D Chen, CO Elson and CT Weaver: Late developmental plasticity in the T helper 17 lineage. Immunity, 30(1), 92-107 (2009)

147. MH Lexberg, A Taubner, I Albrecht, I Lepenies, A Richter, T Kamradt, A Radbruch and HD Chang: IFN-gamma and IL-12 synergize to convert in vivo generated Th17 into Th1/Th17 cells. Eur J Immunol, 40(11), 3017-27 (2010)

148. FC Kurschus, AL Croxford, AP Heinen, S Wortge, D Ielo and A Waisman: Genetic proof for the transient nature of the Th17 phenotype. Eur J Immunol, 40(12), 3336-46 (2010)

149. K Hirota, JH Duarte, M Veldhoen, E Hornsby, Y Li, DJ Cua, H Ahlfors, C Wilhelm, M Tolaini, U Menzel, A Garefalaki, AJ Potocnik and B Stockinger: Fate mapping of IL-17-producing T cells in inflammatory responses. Nat Immunol, 12(3), 255$63(2011)$

150. D Bending, H De la Pena, M Veldhoen, JM Phillips, C Uyttenhove, B Stockinger and A Cooke: Highly purified Th17 cells from BDC2.5NOD mice convert into Th1-like cells in NOD/SCID recipient mice. J Clin Invest, 119(3), 565-72 (2009)

151. F Annunziato and S Romagnani: Mouse T helper 17 phenotype: Not so different than in man after all. Cytokine 56(1):112-5 (2011)

152. BA de Jong, TW Huizinga, EL Bollen, BM Uitdehaag, GP Bosma, MA van Buchem, EJ Remarque, AC Burgmans, NF Kalkers, CH Polman and RG Westendorp: Production of IL-1beta and IL-1Ra as risk factors for susceptibility and progression of relapse-onset multiple sclerosis. J Neuroimmunol, 126(1-2), 172-9 (2002)

153. C Sutton, C Brereton, B Keogh, KH Mills and EC Lavelle: A crucial role for interleukin (IL)-1 in the induction of IL-17producing $\mathrm{T}$ cells that mediate auto-immune encephalomyelitis. J Exp Med, 203(7), 1685-91 (2006)

154. DJ Cua, J Sherlock, Y Chen, CA Murphy, B Joyce, B Seymour, L Lucian, W To, S Kwan, T Churakova, S Zurawski, M Wiekowski, SA Lira, D Gorman, RA Kastelein and JD Sedgwick: Interleukin-23 rather than interleukin-12 is the critical cytokine for auto-immune inflammation of the brain. Nature, 421(6924), 744-8 (2003)

155. CA Murphy, CL Langrish, Y Chen, W Blumenschein, T McClanahan, RA Kastelein, JD Sedgwick and DJ Cua: Divergent pro- and antiinflammatory roles for IL-23 and IL-12 in joint auto-immune inflammation. J Exp Med, 198(12), 1951-7 (2003)

156. SC Liang, XY Tan, DP Luxenberg, R Karim, K Dunussi-Joannopoulos, M Collins and LA Fouser: Interleukin (IL)-22 and IL-17 are coexpressed by Th17 cells and cooperatively enhance expression of antimicrobial peptides. J Exp Med, 203(10), 2271$9(2006)$

157. K Wolk, S Kunz, E Witte, M Friedrich, K Asadullah and R Sabat: IL-22 increases the innate immunity of tissues. Immunity, 21(2), 241-54 (2004)

158. L Yang, DE Anderson, C Baecher-Allan, WD Hastings, E Bettelli, M Oukka, VK Kuchroo and DA Hafler: IL-21 and TGFbeta are required for differentiation of human $\mathrm{T}(\mathrm{H}) 17$ cells. Nature, 454(7202), 350-2 (2008)

159. B Stockinger and M Veldhoen: Differentiation and function of Th17 T cells. Curr Opin Immunol, 19(3), 281-6 (2007)

160. I Sonderegger, J Kisielow, R Meier, C King and M Kopf: IL-21 and IL-21R are not required for development of Th17 cells and auto-immunity in vivo. Eur J Immunol, 38(7), 1833-8 (2008)

161. I Sonderegger, G Iezzi, R Maier, N Schmitz, M Kurrer and M Kopf: GM-CSF mediates auto-immunity by enhancing IL-6dependent Th17 cell development and survival. J Exp Med, 205(10), 2281-94 (2008)

162. RM Grossman, J Krueger, D Yourish, A Granelli-Piperno, DP Murphy, LT May, TS Kupper, PB Sehgal and AB Gottlieb: Interleukin 6 is expressed in high levels in psoriatic skin and stimulates proliferation of cultured human keratinocytes. Proc Natl Acad Sci U S A, 86(16), 6367-71 (1989)

163. P Neuner, A Urbanski, F Trautinger, A Moller, R Kirnbauer, A Kapp, E Schopf, T Schwarz and TA Luger: Increased IL-6 production by monocytes and keratinocytes in patients with psoriasis. J Invest Dermatol, 97(1), 27-33 (1991) 
164. O Boyman, HP Hefti, C Conrad, BJ Nickoloff, M Suter and FO Nestle: Spontaneous development of psoriasis in a new animal model shows an essential role for resident T cells and tumor necrosis factor-alpha. J Exp Med, 199(5), 731-6 (2004)

165. K Ferenczi, L Burack, M Pope, JG Krueger and LM Austin: CD69, HLA-DR and the IL-2R identify persistently activated T cells in psoriasis vulgaris lesional skin: blood and skin comparisons by flow cytometry. J Autoimmun, 14(1), 63-78 (2000)

166. T Wrone-Smith and BJ Nickoloff: Dermal injection of immunocytes induces psoriasis. J Clin Invest, 98(8), 1878-87 (1996)

167. A Di Cesare, P Di Meglio and FO Nestle: The IL-23/Th17 axis in the immunopathogenesis of psoriasis. J Invest Dermatol, $129(6), 1339-50(2009)$

168. WA Goodman, AD Levine, JV Massari, H Sugiyama, TS McCormick and KD Cooper: IL-6 signaling in psoriasis prevents immune suppression by regulatory T cells. J Immunol, 183(5), 3170-6 (2009)

169. C Conrad, O Boyman, G Tonel, A Tun-Kyi, U Laggner, A de Fougerolles, V Kotelianski, H Gardner and FO Nestle: Alphalbeta1 integrin is crucial for accumulation of epidermal T cells and the development of psoriasis. Nat Med, 13(7), 836-42 (2007)

170. TP Singh, MP Schon, K Wallbrecht, K Michaelis, B Rinner, G Mayer, U Schmidbauer, H Strohmaier, XJ Wang and P Wolf: 8-methoxypsoralen plus ultraviolet A therapy acts via inhibition of the IL-23/Th17 axis and induction of Foxp3 ${ }^{+}$regulatory T cells involving CTLA4 signaling in a psoriasis-like skin disorder. J Immunol, 184(12), 7257-67 (2010)

171. MA Lowes, T Kikuchi, J Fuentes-Duculan, I Cardinale, LC Zaba, AS Haider, EP Bowman and JG Krueger: Psoriasis vulgaris lesions contain discrete populations of Th1 and Th17 T cells. J Invest Dermatol, 128(5), 1207-11 (2008)

172. MA Nowell, AS Williams, SA Carty, J Scheller, AJ Hayes, GW Jones, PJ Richards, S Slinn, M Ernst, BJ Jenkins, N Topley, S Rose-John and SA Jones: Therapeutic targeting of IL-6 trans signaling counteracts STAT3 control of experimental inflammatory arthritis. J Immunol, 182(1), 613-22 (2009)

173. A Doganci, T Eigenbrod, N Krug, GT De Sanctis, M Hausding, VJ Erpenbeck, B Haddad el, HA Lehr, E Schmitt, T Bopp, KJ Kallen, U Herz, S Schmitt, C Luft, O Hecht, JM Hohlfeld, H Ito, N Nishimoto, K Yoshizaki, T Kishimoto, S Rose-John, H Renz, MF Neurath, PR Galle and S Finotto: The IL-6R alpha chain controls lung CD4 ${ }^{+}$CD25 ${ }^{+}$Treg development and function during allergic airway inflammation in vivo. J Clin Invest, 115(2), 313-25 (2005)

174. RM McLoughlin, BJ Jenkins, D Grail, AS Williams, CA Fielding, CR Parker, M Ernst, N Topley and SA. Jones: IL-6 transsignaling via STAT3 directs T cell infiltration in acute inflammation. Proc Natl Acad Sci U S A, 102(27), 9589-94 (2005)

175. GW Jones, RM McLoughlin, VJ Hammond, CR Parker, JD Williams, R Malhotra, J Scheller, AS Williams, S Rose-John, N Topley and SA Jones: Loss of CD4 ${ }^{+} \mathrm{T}$ cell IL-6R expression during inflammation underlines a role for IL- 6 trans signaling in the local maintenance of Th17 cells. J Immunol, 184(4), 2130-9 (2010)

176. C Pasare and R Medzhitov: Toll pathway-dependent blockade of $\mathrm{CD} 4^{+} \mathrm{CD} 25^{+} \mathrm{T}$ cell-mediated suppression by dendritic cells. Science, 299(5609), 1033-6 (2003)

177. I Rochman, WE Paul and SZ Ben-Sasson: IL-6 increases primed cell expansion and survival. J Immunol, 174(8), 4761-7 (2005)

178. J Wang, RJ Homer, Q Chen and JA Elias: Endogenous and exogenous IL-6 inhibits aeroallergen-induced Th2 inflammation. J Immunol, 165(7), 4051-61 (2000)

179. EM Briso, O Dienz and M Rincon: Cutting edge: soluble IL-6R is produced by IL-6R ectodomain shedding in activated CD4 T cells. J Immunol, 180(11), 7102-6 (2008)

180. M Nishihara, H Ogura, N Ueda, M Tsuruoka, C Kitabayashi, F Tsuji, H Aono, K Ishihara, E Huseby, UA Betz, M Murakami and T Hirano: IL-6-gp130-STAT3 in T cells directs the development of IL-17 $7^{+}$Th with a minimum effect on that of Treg in the steady state. Int Immunol, 19(6), 695-702 (2007)

181. L Zhou, Ivanov, II, R Spolski, R Min, K Shenderov, T Egawa, DE Levy, WJ Leonard and DR Littman: IL-6 programs T(H)17 cell differentiation by promoting sequential engagement of the IL-21 and IL-23 pathways. Nat Immunol, 8(9), 967-74 (2007) 
182. XO Yang, AD Panopoulos, R Nurieva, SH Chang, D Wang, SS Watowich and C Dong: STAT3 regulates cytokine-mediated generation of inflammatory helper T cells. J Biol Chem, 282(13), 9358-63 (2007)

183. TJ Harris, JF Grosso, HR Yen, H Xin, M Kortylewski, E Albesiano, EL Hipkiss, D Getnet, MV Goldberg, CH Maris, F Housseau, H Yu, DM Pardoll and CG Drake: Cutting edge: An in vivo requirement for STAT3 signaling in TH17 development and TH17-dependent auto-immunity. J Immunol, 179(7), 4313-7 (2007)

184. Z Chen, A Laurence, Y Kanno, M Pacher-Zavisin, BM Zhu, C Tato, A Yoshimura, L Hennighausen and JJ O'Shea: Selective regulatory function of Socs3 in the formation of IL-17-secreting T cells. Proc Natl Acad Sci U S A, 103(21), 8137-42 (2006)

185. R Zeng, R Spolski, E Casas, W Zhu, DE Levy and WJ Leonard: The molecular basis of IL-21-mediated proliferation. Blood, 109(10), 4135-42 (2007)

186. AM Akimzhanov, XO Yang and C Dong: Chromatin remodeling of interleukin-17 (IL-17)-IL-17F cytokine gene locus during inflammatory helper T cell differentiation. J Biol Chem, 282(9), 5969-72 (2007)

187. L Durant, WT Watford, HL Ramos, A Laurence, G Vahedi, L Wei, H Takahashi, HW Sun, Y Kanno, F Powrie and JJ O'Shea: Diverse targets of the transcription factor STAT3 contribute to T cell pathogenicity and homeostasis. Immunity, 32(5), 605-15 (2010)

188. A Laurence, CM Tato, TS Davidson, Y Kanno, Z Chen, Z Yao, RB Blank, F Meylan, R Siegel, L Hennighausen, EM Shevach and J O'Shea J: Interleukin-2 signaling via STAT5 constrains T helper 17 cell generation. Immunity, 26(3), 371-81 (2007)

189. Y Minegishi, M Saito, S Tsuchiya, I Tsuge, H Takada, T Hara, N Kawamura, T Ariga, S Pasic, O Stojkovic, A Metin and H Karasuyama: Dominant-negative mutations in the DNA-binding domain of STAT3 cause hyper-IgE syndrome. Nature, 448(7157), 1058-62 (2007)

190. SM Holland, FR DeLeo, HZ Elloumi, AP Hsu, G Uzel, N Brodsky, AF Freeman, A Demidowich, J Davis, ML Turner, VL Anderson, DN Darnell, PA Welch, DB Kuhns, DM Frucht, HL Malech, JI Gallin, SD Kobayashi, AR Whitney, JM Voyich, JM Musser, C Woellner, AA Schaffer, JM Puck and B Grimbacher: STAT3 mutations in the hyper-IgE syndrome. N Engl J Med, $357(16), 1608-19(2007)$

191. JD Milner, JM Brenchley, A Laurence, AF Freeman, BJ Hill, KM Elias, Y Kanno, C Spalding, HZ Elloumi, ML Paulson, J Davis, A Hsu, AI Asher, J O'Shea, SM Holland, WE Paul and DC Douek: Impaired T(H)17 cell differentiation in subjects with autosomal dominant hyper-IgE syndrome. Nature, 452(7188), 773-6 (2008)

192. CS Ma, GY Chew, N Simpson, A Priyadarshi, M Wong, B Grimbacher, DA Fulcher, SG Tangye and MC Cook: Deficiency of Th17 cells in hyper IgE syndrome due to mutations in STAT3. J Exp Med, 205(7), 1551-7 (2008)

193. CE Egwuagu: STAT3 in CD4 ${ }^{+}$T helper cell differentiation and inflammatory diseases. Cytokine, 47(3), 149-56 (2009)

194. A Chaudhry, D Rudra, P Treuting, RM Samstein, Y Liang, A Kas and AY Rudensky: CD4 ${ }^{+}$regulatory T cells control TH17 responses in a Stat3-dependent manner. Science, 326(5955), 986-91 (2009)

195. A Chaudhry, RM Samstein, P Treuting, Y Liang, MC Pils, JM Heinrich, RS Jack, FT Wunderlich, JC Bruning, W Muller and AY Rudensky: Interleukin-10 signaling in regulatory T cells is required for suppression of Th17 cell-mediated inflammation. Immunity, 34(4), 566-78 (2011)

196. M Kortylewski, H Xin, M Kujawski, H Lee, Y Liu, T Harris, C Drake, D Pardoll and H Yu: Regulation of the IL-23 and IL12 balance by Stat3 signaling in the tumor microenvironment. Cancer Cell, 15(2), 114-23 (2009)

197. MC Cenit, A Alcina, A Marquez, JL Mendoza, M Diaz-Rubio, V de las Heras, G Izquierdo, R Arroyo, O Fernandez, EG de la Concha, F Matesanz and E Urcelay: STAT3 locus in inflammatory bowel disease and multiple sclerosis susceptibility. Genes Immun, 11(3), 264-8 (2010)

198. T Shouda, T Yoshida, T Hanada, T Wakioka, M Oishi, K Miyoshi, S Komiya, K Kosai, Y Hanakawa, K Hashimoto, K Nagata and A Yoshimura: Induction of the cytokine signal regulator SOCS3/CIS3 as a therapeutic strategy for treating inflammatory arthritis. J Clin Invest, 108(12), 1781-8 (2001) 
199. A Krause, N Scaletta, JD Ji and LB Ivashkiv: Rheumatoid arthritis synoviocyte survival is dependent on Stat3. J Immunol, $169(11), 6610-6$ (2002)

200. T Ohtani, K Ishihara, T Atsumi, K Nishida, Y Kaneko, T Miyata, S Itoh, M Narimatsu, H Maeda, T Fukada, M Itoh, H Okano, M Hibi and T Hirano: Dissection of signaling cascades through gp130 in vivo: reciprocal roles for STAT3- and SHP2mediated signals in immune responses. Immunity, 12(1), 95-105 (2000)

201. NC Tebbutt, AS Giraud, M Inglese, B Jenkins, P Waring, FJ Clay, S Malki, BM Alderman, D Grail, F Hollande, JK Heath and M Ernst: Reciprocal regulation of gastrointestinal homeostasis by SHP2 and STAT-mediated trefoil gene activation in gp130 mutant mice. Nat Med, 8(10), 1089-97 (2002)

202. T Atsumi, K Ishihara, D Kamimura, H Ikushima, T Ohtani, S Hirota, H Kobayashi, SJ Park, Y Saeki, Y Kitamura and T Hirano: A point mutation of Tyr-759 in interleukin 6 family cytokine receptor subunit gp130 causes auto-immune arthritis. J Exp Med, 196(7), 979-90 (2002)

203. M Ernst, M Najdovska, D Grail, T Lundgren-May, M Buchert, H Tye, VB Matthews, J Armes, PS Bhathal, NR Hughes, EG Marcusson, JG Karras, S Na, JD Sedgwick, PJ Hertzog and BJ Jenkins: STAT3 and STAT1 mediate IL-11-dependent and inflammation-associated gastric tumorigenesis in gp130 receptor mutant mice. J Clin Invest, 118(5), 1727-38 (2008)

204. M Ernst and BJ Jenkins: Acquiring signalling specificity from the cytokine receptor gp130. Trends Genet, 20(1), 23-32 (2004)

205. H Ogura, M Murakami, Y Okuyama, M Tsuruoka, C Kitabayashi, M Kanamoto, M Nishihara, Y Iwakura and T Hirano: Interleukin-17 promotes auto-immunity by triggering a positive-feedback loop via interleukin-6 induction. Immunity, 29(4), 628$36(2008)$

206. JS Fridman, PA Scherle, R Collins, TC Burn, Y Li, J Li, MB Covington, B Thomas, P Collier, MF Favata, X Wen, J Shi, R McGee, PJ Haley, S Shepard, JD Rodgers, S Yeleswaram, G Hollis, RC Newton, B Metcalf, SM Friedman and K Vaddi: Selective inhibition of JAK1 and JAK2 is efficacious in rodent models of arthritis: preclinical characterization of INCB028050. J Immunol, 184(9), 5298-307 (2010)

207. M Chen, G Chen, H Nie, X Zhang, X Niu, YC Zang, SM Skinner, JZ Zhang, JM Killian and J Hong: Regulatory effects of IFN-beta on production of osteopontin and IL-17 by CD4 ${ }^{+}$T Cells in MS. Eur J Immunol, 39(9), 2525-36 (2009)

208. E Waubant, S Vukusic, L Gignoux, FD Dubief, I Achiti, S Blanc, C Renoux and C Confavreux: Clinical characteristics of responders to interferon therapy for relapsing MS. Neurology, 61(2), 184-9 (2003)

209. S Zhang, M Zheng, R Kibe, Y Huang, L Marrero, S Warren, AW Zieske, T Iwakuma, JK Kolls and Y Cui: Trp53 negatively regulates auto-immunity via the STAT3-Th17 axis. FASEB J, 25(7), 2387-98 (2011)

210. F Yang, WF Wu, YL Yan, Y Pang, Q Kong and YL Huang: Expression of IL-23/Th17 Pathway in a Murine Model of Coxsackie Virus B3-Induced Viral Myocarditis. Virol J, 8(1), 301 (2011)

211. M Karin and FR Greten: NF-kappaB: linking inflammation and immunity to cancer development and progression. Nat Rev Immunol, 5(10), 749-59 (2005)

212. SI Grivennikov, FR Greten and M Karin: Immunity, inflammation, and cancer. Cell, 140(6), 883-99 (2010)

213. A Mantovani, P Allavena, A Sica and F Balkwill: Cancer-related inflammation. Nature, 454(7203), 436-44 (2008)

214. MJ Waldner and MF Neurath: Colitis-associated cancer: the role of T cells in tumor development. Semin Immunopathol, $31(2), 249-56(2009)$

215. K Mitsuyama, S Matsumoto, S Rose-John, A Suzuki, T Hara, N Tomiyasu, K Handa, O Tsuruta, H Funabashi, J Scheller, A Toyonaga and M Sata: STAT3 activation via interleukin 6 trans-signalling contributes to ileitis in SAMP1/Yit mice. Gut, 55(9), $1263-9(2006)$

216. R Atreya and MF Neurath: Involvement of IL-6 in the pathogenesis of inflammatory bowel disease and colon cancer. Clin Rev Allergy Immunol, 28(3), 187-96 (2005)

217. AC Bharti, N Donato and BB Aggarwal: Curcumin (diferuloylmethane) inhibits constitutive and IL-6-inducible STAT3 phosphorylation in human multiple myeloma cells. J Immunol, 171(7), 3863-71 (2003) 
218. S Liu, Z Ma, H Cai, Q Li, W Rong and M Kawano: Inhibitory effect of baicalein on IL-6-mediated signaling cascades in human myeloma cells. Eur J Haematol, 84(2), 137-44 (2010)

219. S Grivennikov, E Karin, J Terzic, D Mucida, GY Yu, S Vallabhapurapu, J Scheller, S Rose-John, H Cheroutre, L Eckmann and M Karin: IL-6 and Stat3 are required for survival of intestinal epithelial cells and development of colitis-associated cancer. Cancer Cell, 15(2), 103-13 (2009)

220. S Matsumoto, T Hara, K Mitsuyama, M Yamamoto, O Tsuruta, M Sata, J Scheller, S Rose-John, S Kado and T Takada: Essential roles of IL-6 trans-signaling in colonic epithelial cells, induced by the IL-6/soluble-IL-6 receptor derived from lamina propria macrophages, on the development of colitis-associated premalignant cancer in a murine model. $\mathrm{J}$ Immunol, 184(3), 1543-51 (2010)

221. CW Lo, MW Chen, M Hsiao, S Wang, CA Chen, SM Hsiao, JS Chang, TC Lai, S Rose-John, ML Kuo and LH Wei: IL-6 trans-signaling in formation and progression of malignant ascites in ovarian cancer. Cancer Res, 71(2):424-34 (2011)

222. Y Miyahara, K Odunsi, W Chen, G Peng, J Matsuzaki and RF Wang: Generation and regulation of human CD4 ${ }^{+}$IL-17producing T cells in ovarian cancer. Proc Natl Acad Sci U S A, 105(40), 15505-10 (2008)

223. JP Zhang, J Yan, J Xu, XH Pang, MS Chen, L Li, C Wu, SP Li and L Zheng: Increased intratumoral IL-17-producing cells correlate with poor survival in hepatocellular carcinoma patients. J Hepatol, 50(5), 980-9 (2009)

224. MM Moradi, LF Carson, B Weinberg, AF Haney, LB Twiggs and S Ramakrishnan: Serum and ascitic fluid levels of interleukin-1, interleukin-6, and tumor necrosis factor-alpha in patients with ovarian epithelial cancer. Cancer, 72(8), 2433-40 (1993)

225. N Martin-Orozco, P Muranski, Y Chung, XO Yang, T Yamazaki, S Lu, P Hwu, NP Restifo, WW Overwijk and C Dong: T helper 17 cells promote cytotoxic T cell activation in tumor immunity. Immunity, 31(5), 787-98 (2009)

226. I Kryczek, S Wei, W Szeliga, L Vatan and W Zou: Endogenous IL-17 contributes to reduced tumor growth and metastasis. Blood, 114(2), 357-9 (2009)

227. L Wang, T Yi, M Kortylewski, DM Pardoll, D Zeng and H Yu: IL-17 can promote tumor growth through an IL-6-Stat3 signaling pathway. J Exp Med, 206(7), 1457-64 (2009)

228. D He, H Li, N Yusuf, CA Elmets, J Li, JD Mountz and H Xu: IL-17 promotes tumor development through the induction of tumor promoting microenvironments at tumor sites and myeloid-derived suppressor cells. J Immunol, 184(5), 2281-8 (2010)

229. L Wang, T Yi, W Zhang, DM Pardoll and H Yu: IL-17 Enhances Tumor Development in Carcinogen-Induced Skin Cancer. Cancer Res, 70(24), 10112-20 (2010)

230. S Sano, S Itami, K Takeda, M Tarutani, Y Yamaguchi, H Miura, K Yoshikawa, S Akira and J Takeda: Keratinocyte-specific ablation of Stat3 exhibits impaired skin remodeling, but does not affect skin morphogenesis. Embo J, 18(17), 4657-68 (1999)

231. CL Kennedy, M Najdovska, GW Jones, L McLeod, NR Hughes, C Allison, C Huey Ooi, P Tan, RL Ferrero, SA Jones, A Dev, W Sievert, PS Bhathal and BJ Jenkins: The molecular pathogenesis of STAT3-driven gastric tumourigenesis in mice is independent of IL-17. J Pathol, 225(2), 255-64 (2011)

232. M Trikha, R Corringham, B Klein and JF Rossi: Targeted anti-interleukin-6 monoclonal antibody therapy for cancer: a review of the rationale and clinical evidence. Clin Cancer Res, 9(13), 4653-65 (2003)

Key Words: IL-6, STAT3, Auto-immunity, sIL-6R, Cytokines, Th17, Review

Send correspondence to: Valeria Poli, Molecular Biotechnology Center, via Nizza 52, 10126 Torino, Tel: 39-116706428, Fax: 39-116706432, E-mail: valeria.poli@unito.it

Figure 1. IL-6 signalling and trans-signalling. IL-6 interacts with its ligand-binding receptor, the IL-6Ralpha, either membranebound (classical signaling) or in a soluble form (trans-signaling), and the complex associates with gp130 triggering its dimerization and consequent activation of the associated JAK kinases. These mediate the phosphorylation of specific tyrosine residues $(\mathrm{P})$ on the gp130 cytoplasmic tail, which in turn act as docking sites for STAT3 (and STAT1) SH2 domains, leading to JAK-mediated STAT3 phosphorylation, dimerization and concentration in the nucleus, where it regulates transcription of target genes. SOCS3 negatively regulates IL-6 signaling by interacting with gp130 phosphotyrosine-759 and leading to the inhibition of 
JAK activity through its kinase inhibitory region. Soluble forms of both IL-6Ralpha and gp130 (sIL-6Ralpha, sgp130), which lack the transmembrane and cytoplasmic parts, are highly produced under pathological conditions, acting as IL-6 trans-signaling agonist (sIL-6Ralpha) or antagonist (sgp130), respectively.

Figure 2. The positive feedback loop between IL-6, IL-17 and STAT3. IL-6 in combination with TGFbeta promotes STAT3dependent Th17 differentiation of naïve $\mathrm{CD}^{+} \mathrm{T}$ cells, while TGFbeta in the absence of IL-6 triggers the differentiation of TGFbeta T regulatory cells (Tregs). The proinflammatory cytokine IL-23 triggers Th17 expansion, but full responsiveness to IL23 requires STAT3-dependent IL-23R up-regulation by IL-6. IL-17, the main cytokine produced by Th17 cells, provides defence against extracellular bacteria and mediates inflammation, tissue damage and recruitment of immune cells. IL-17 acts on stromal cells to sustain NF-kB-mediated IL-6 expression, which in turn enhances Th17 differentiation in a positive feedback loop. In addition, stimulated stromal cells attract neutrophils, which generate sIL-6R by shedding thus leading to trans-signaling in combination with IL-6, further amplifying and sustaining inflammation. $\square$, membrane-bound IL-6 receptor; $\square$, membrane-bound IL-23 receptor; red P-ST3 or NF-kB indicate phospho-STAT3 or NF-kB dependent effects.

Running title: IL-6, STAT-3 and IL-17 contribution to auto-immunity 


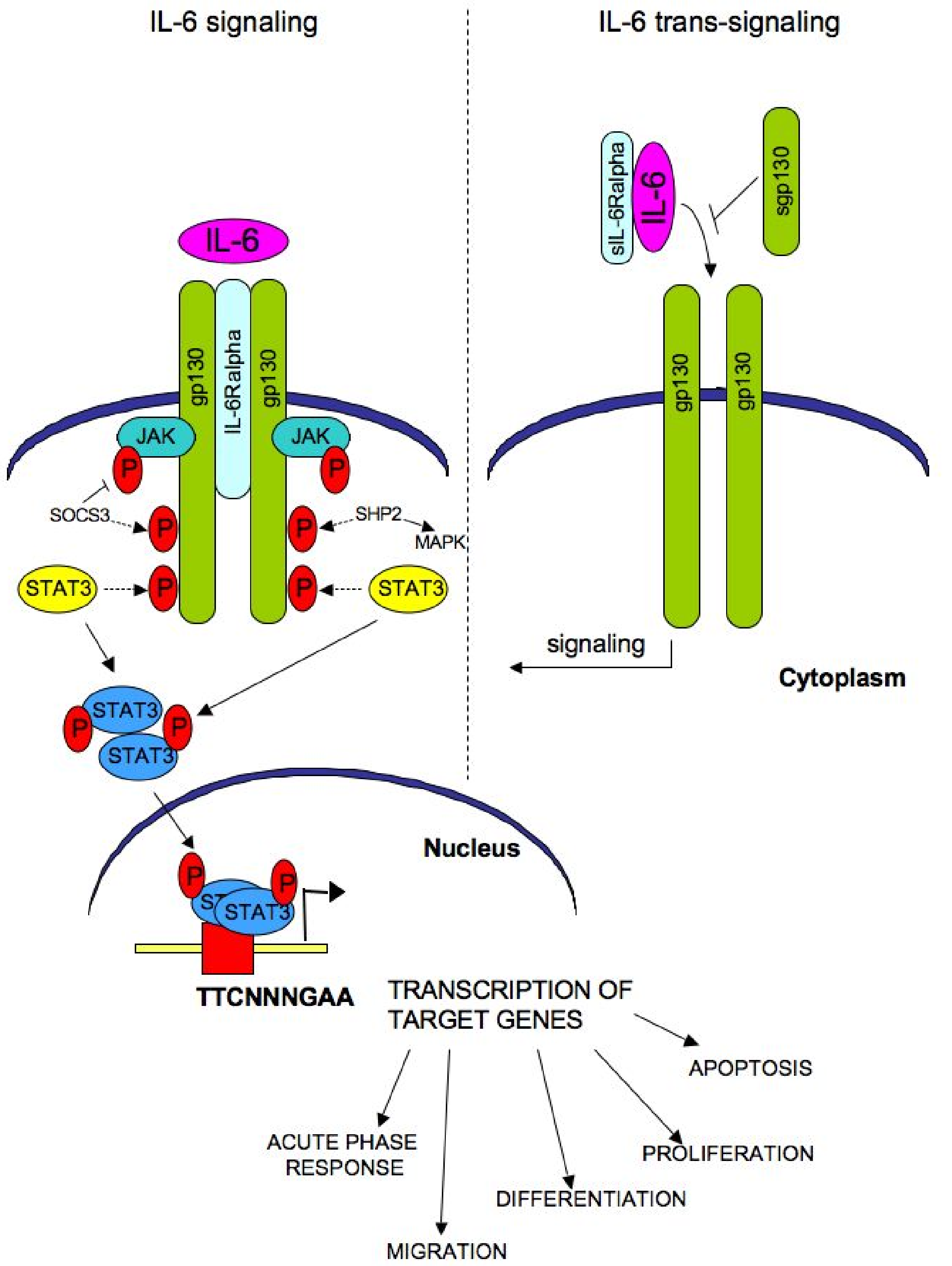




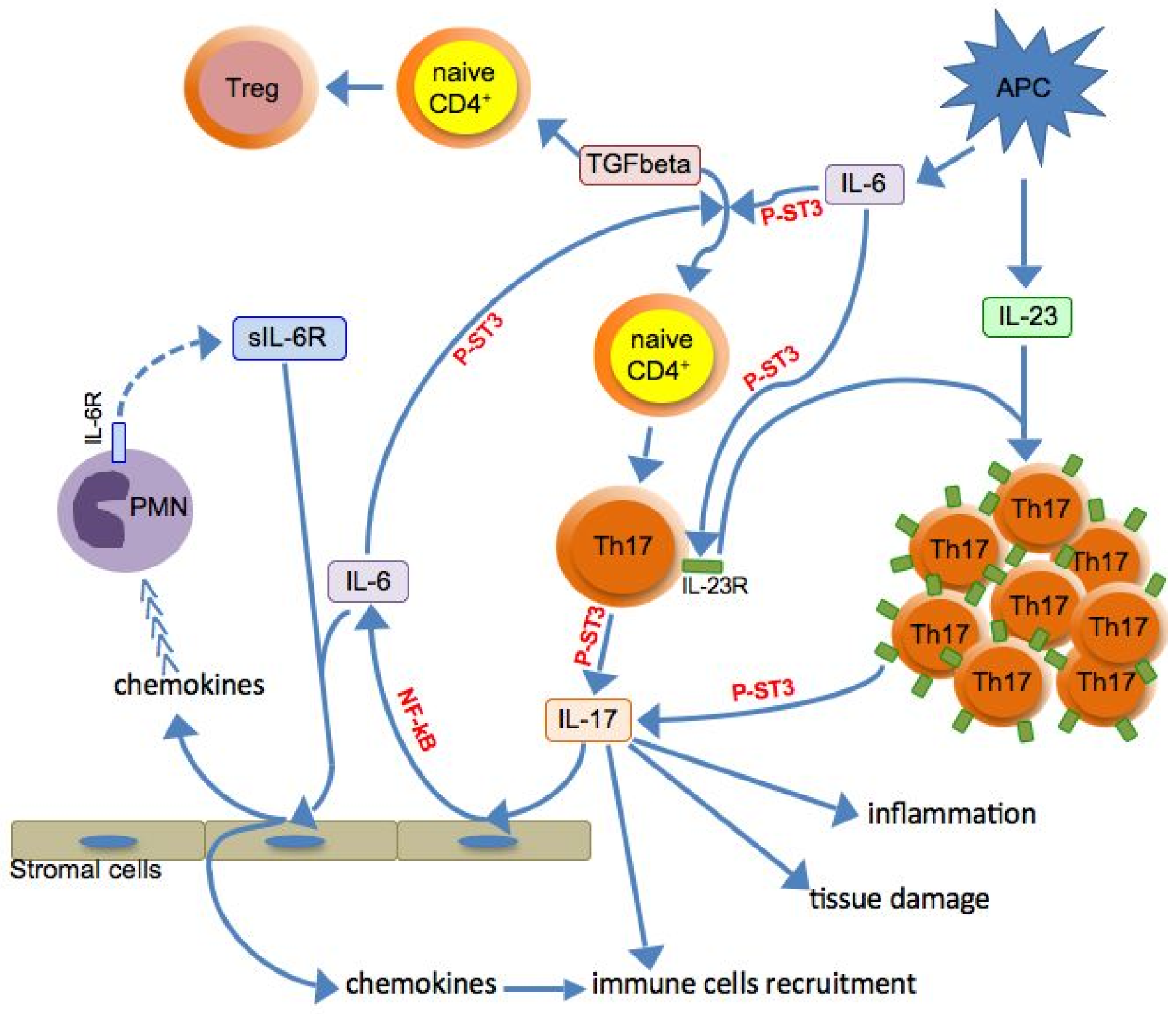

